\title{
High radiofrequency radiation at Stockholm Old Town: An exposimeter study including the Royal Castle, Supreme Court, three major squares and the Swedish Parliament
}

\author{
LENNART HARDELL $^{1}$, MICHAEL CARLBERG ${ }^{1}$, TARMO KOPPEL $^{2}$ and LENA HEDENDAHL ${ }^{3}$ \\ ${ }^{1}$ Department of Oncology, Faculty of Medicine and Health, Örebro University, SE-701 82 Örebro, \\ Sweden; ${ }^{2}$ Department of Labour Environment and Safety, Tallinn University of Technology, 19086 Tallinn, \\ Estonia; ${ }^{3}$ Independent Environment and Health Research Luleå, SE-972 53 Luleå, Sweden
}

Received October 17, 2016; Accepted January 30, 2017

DOI: $10.3892 / \mathrm{mco} .2017 .1180$

\begin{abstract}
Exposure to radiofrequency (RF) radiation was classified as a possible human carcinogen, Group 2B, by the International Agency for Research on Cancer at WHO in 2011. The exposure pattern is changing due to the rapid development of technology. Outdoor RF radiation level was measured during five tours in Stockholm Old Town in April, 2016 using the EME Spy 200 exposimeter with 20 predefined frequencies. The results were based on 10,437 samples in total. The mean level of the total RF radiation was $4,293 \mu \mathrm{W} / \mathrm{m}^{2}$ $\left(0.4293 \mu \mathrm{W} / \mathrm{cm}^{2}\right)$. The highest mean levels were obtained for global system for mobile communications (GSM) + universal mobile telecommunications system (UMTS) 900 downlink and long-term evolution (LTE) 2600 downlink (1,558 and $1,265 \mu \mathrm{W} / \mathrm{m}^{2}$, respectively). The town squares displayed highest total mean levels, with the example of Järntorget square with $24,277 \mu \mathrm{W} / \mathrm{m}^{2}\left(\min 257, \max 173,302 \mu \mathrm{W} / \mathrm{m}^{2}\right)$. These results were in large contrast to areas with lowest total exposure, such as the Supreme Court, with a mean level of $404 \mu \mathrm{W} / \mathrm{m}^{2}$ $\left(\min 20.4, \max 4,088 \mu \mathrm{W} / \mathrm{m}^{2}\right)$. In addition, measurements in the streets surrounding the Royal Castle were lower than the total for the Old Town, with a mean of $756 \mu \mathrm{W} / \mathrm{m}^{2}(\min 0.3$, $\left.\max 50,967 \mu \mathrm{W} / \mathrm{m}^{2}\right)$. The BioInitiative 2012 Report defined the scientific benchmark for possible health risks as $30-60 \mu \mathrm{W} / \mathrm{m}^{2}$. Our results of outdoor RF radiation exposure at Stockholm Old Town are significantly above that level. The mean exposure level at Järntorget square was 405 -fold higher than $60 \mu \mathrm{W} / \mathrm{m}^{2}$. Our results were below the reference level on 10,000,000 $\mu \mathrm{W} / \mathrm{m}^{2}$ established by the International Commission on Non-Ionizing
\end{abstract}

Correspondence to: Professor Lennart Hardell, Department of Oncology, Faculty of Medicine and Health, Örebro University, Långhuset, Fakultetsgatan 1, SE-701 82 Örebro, Sweden

E-mail: lennart.hardell@regionorebrolan.se

Key words: radiofrequency radiation, radiofrequency electromagnetic field, base stations, exposimeter, public exposure, health, cancer
Radiation Protection (ICNIRP), which, however, are less credible, as they do not take non-thermal effects into consideration and are not based on sound scientific evaluation. Our highest measured mean level at Järntorget was $0.24 \%$ of the ICNIRP level. A number of studies have found adverse, non-thermal (no measurable temperature increase) health effects far below the ICNIRP guidelines.

\section{Introduction}

The results of a study on public exposure to radiofrequency (RF) radiation at the Stockholm Central Railway Station in Sweden were recently published (1). The exposimeter EME Spy 200 that covers 20 different radiofrequency bands from 87 to $5,850 \mathrm{MHz}$ was used. The results were based on 1,669 data points recorded in November, 2015. The median value for total exposure was $921 \mu \mathrm{W} / \mathrm{m}^{2}\left(0.092 \mu \mathrm{W} / \mathrm{cm}^{2}\right)$, with certain outliers $>95,544 \mu \mathrm{W} / \mathrm{m}^{2}$ ( $6 \mathrm{~V} / \mathrm{m}$, which is the upper detection limit). One example of such very high measured power density was from a global system for mobile communications (GSM) + universal mobile telecommunications system (UMTS) 900 downlink band from a base station located at the Stockholm Central Station lower level (1). People standing at that area or passing by are involuntarily exposed to high $\mathrm{RF}$ radiation without their knowledge. It was concluded that this represented an improper location of a base station with an unnecessary high downlink level.

In European countries, the Old Town is a point of a national heritage, a place and source of cultural and historical development throughout centuries. Stockholm Old Town has already been retrofitted with several existing antennas to accommodate voice and data transmission. The aim of the present study was to characterize $\mathrm{RF}$ radiation already in place and its effect on the public. The antenna grid is expected to be further expanded to accommodate the rollout of $5 \mathrm{G}$ mobile networking as the next wave of mobile technology is implemented. As mobile base station antennas are placed on rooftops, outer walls of buildings and other places, visual perturbations appear in the form of antenna casings, cables and other peripheral devices. Not only does this damage the aesthetic appearance of the historic districts of the Old Town, 
but it is associated with exposure of the public to invisible RF radiation. Even where hidden antennas have been architecturally camouflaged (stealth installations), the RF radiation exposure is still present and remains a growing concern for environmental health.

The most drastic change brought about by the mobile telephony network is the change in the electromagnetic climate. The streets of old towns are filled with visually imperceptible RF radiation. As modern mobile telephony and data networking provide services at several different bands, there are different frequencies that also require band-specific antennas, therefore multiplying the number of antennas.

One major concern regarding $\mathrm{RF}$ radiation exposure in Sweden, as well as in a number of other countries, is that various authorities base their guidelines for exposure on the International Commission on Non-Ionizing Radiation Protection's (ICNIRP) guidelines that are based on short-term (acute) exposure. Chronic, low-intensity cumulative exposure, possible long-term health risks and non-thermal biological effects are not taken into consideration. The ICNIRP safety limit was established in 1998 (2) and updated in 2009 (3), without any further changes, and it still recommends $10 \mathrm{~W} / \mathrm{m}^{2}$ $\left(10,000,000 \mu \mathrm{W} / \mathrm{m}^{2}\right)$ as the reference level for limiting the public's exposure to RF radiation (2-300 GHz) (2). The Swedish Radiation Safety Authority (SSM) has adopted the ICNIRP guidelines. Several members of the SSM expert panel are also members of ICNIRP, which may entail a conflict of interest, since these members would rarely compromise the ICNIRP view so that critical opinions are not heard.

Our results on public RF radiation exposure at the Stockholm Central Station are orders of magnitude lower than the ICNIRP guidelines, where the median level of exposure was $\sim 10,000$ times lower. Wireless internet access in schools is also a concern (4), although measurements of levels are scanty.

In contrast to ICNIRP, the BioInitiative Reports from 2007 (5), updated in 2012 (6), also based their evaluation on the non-thermal effects of RF radiation. The BioInitiative 2012 Report assessed $\sim 1,800$ new peer-reviewed studies published between 2006 and 2012 that documented the new and lower scientific benchmark for health harm to be $30-60 \mu \mathrm{W} / \mathrm{m}^{2}$ (0.003-0.006 $\left.\mu \mathrm{W} / \mathrm{cm}^{2}\right)$, which is $0.0003-0.0006 \%$ below ICNIRP's guidelines. Also considering chronic exposure and sensitivity among children, the precautionary target level was proposed to be one-tenth of this value, namely 3-6 $\mu \mathrm{W} / \mathrm{m}^{2}$ (6). This exposure target level is not acknowledged by SSM, thus making it possible to overlook results on exposure, such as those at the Stockholm Central Station, and not providing precautions against potential detrimental effects on public health.

Interestingly, scientific evidence on the carcinogenic potential of RF radiation in laboratory studies has long been accumulating, but has mostly been ignored or entirely overlooked by decision-makers.

In 1982, Szmigielski et al published a study on the co-carcinogenic effects of RF radiation exposure and benzopyrene in mice (7) and demonstrated that 2,450 $\mathrm{MHz}$ of $\mathrm{RF}$ radiation at either 50 or $150 \mathrm{~W} / \mathrm{m}^{2}$ promoted carcinogenesis. The authors concluded that the resulting acceleration of development of spontaneous and chemically induced cancers indicated the carcinogenic potential of RF radiation.
Two studies published in 1990 demonstrated that non-thermal 2,450 MHz continuous-wave RF radiation exerted a biphasic effect on glioma cells (8) and lymphocytes (9). Cell proliferation was found at a specific absorption rate (SAR) of $\leq 50 \mathrm{~W} / \mathrm{kg}$, whereas a higher SAR suppressed DNA and RNA synthesis. These effects were reported to be non-thermal.

In 1992, Chou et al published a study on 200 rats exposed to $2,450 \mathrm{MHz}$ pulsed $\mathrm{RF}$ radiation for $21.5 \mathrm{~h}$ /day for 25 months and 200 controls (10). SAR ranged between 0.144 and $0.4 \mathrm{~W} / \mathrm{kg}$, depending on the rat's weight. A statistically significantly increased incidence of primary malignant diseases was found in exposed animals compared with sham exposure. It should be noted that malignant lymphoma and thyroid cancer were among the malignancies found in exposed rats. These findings are interesting in view of the low SAR values in that study compared with the ICNIRP safety limit of SAR $2 \mathrm{~W} / \mathrm{kg}$ in the brain for use of mobile phones (2).

In 1997, a study on mice carrying a lymphomagenic oncogene exposed to RF radiation was published (11). A total of 100 mice were sham-exposed and 101 were exposed for two 30-min periods per day for up to 18 months to $900 \mathrm{MHz}$ pulsed $\mathrm{RF}$ radiation with power densities of 2.6-13 W/m² (SAR 0.008-4.2 W/kg; mean, 0.13-1.4 W/kg). The lymphoma risk was found to be statistically significantly higher in the exposed mice compared with that in the controls.

Those results were not confirmed in the study by Utteridge et al (12), which has been criticized for not being a replication study. However, the findings on lymphoma risk by Repacholi et al (11) and Chou et al (10) are of relevance in terms of increased non-Hodgkin lymphoma (NHL) risk in epidemiological studies on humans associated with the use of wireless phones. Thus, a statistically significantly increased risk of T-cell NHL was found in a previous study [odds ratio $(\mathrm{OR})=8.75](13)$ and in a second study for all NHL cases among subjects with $>6$ years of mobile phone use $(\mathrm{OR}=4.4$ in men) (14), although based on limited numbers. Furthermore, the finding of thyroid cancer risk in the Chou et al study (10) is interesting in view of the sharp increase in the incidence of thyroid cancer during recent years (15). The thyroid gland is among the organs with highest exposure to RF radiation during use of handheld wireless phones, particularly smartphones $(16,17)$.

The effects on tumour susceptibility in mice exposed to a UMTS test signal from the fetal period for up to 24 months was studied by Tillman et al (18). Animals were exposed to UMTS fields with intensities of $0,4.8$ and $48 \mathrm{~W} / \mathrm{m}^{2}$. The low-dose group $\left(4.8 \mathrm{~W} / \mathrm{m}^{2}\right)$ was subjected to additional prenatal ethylnitrosourea (ENU) treatment. The group that was ENU-treated and UMTS-exposed at $4.8 \mathrm{~W} / \mathrm{m}^{2}$ exhibited an increased rate of lung tumours and an increased incidence of lung carcinomas as compared with the controls treated with ENU alone. The authors concluded that the study demonstrated a co-carcinogenic effect of lifelong UMTS exposure in female mice subjected to pretreatment with ENU (18).

A follow-up study of the Tillman et al investigation was published in 2015 (19). The exposure levels were 0 (sham), $0.04,0.4$ and $2 \mathrm{~W} / \mathrm{kg}$ SAR. The numbers of lung and liver tumours in exposed animals were statistically significantly higher compared with those in sham-exposed controls, as were the numbers of malignant lymphoma. A tumour-promoting 
effect of RF radiation was found at low to moderate levels ( 0.04 and $0.4 \mathrm{~W} / \mathrm{kg} \mathrm{SAR}$ ), which were well below the exposure limits for users of mobile phones (19).

A report was released from The National Toxicology Program (NTP) under the National Institutes of Health (NIH) in USA on the largest ever animal study on cell phone RF radiation and cancer (20). An increased incidence of glioma in the brain and malignant schwannoma in the heart was found. Acoustic neuroma or vestibular schwannoma is a similar type of tumour as the one found in the heart, although benign. The use of mobile as well as cordless phones has been associated with increased risk for glioma and acoustic neuroma in humans, as described below.

The same RF radiation that led male rats to develop brain tumours in the NTP study also caused DNA breaks in their brains. Female rats, which did not have statistically significantly elevated tumour counts, had fewer DNA breaks (http://microwavenews.com/news-center/ntp-comet-assay). According to Ron Melnick, who led the team that designed the NTP study, the results provide 'strong evidence for the genotoxicity of cell phone radiation' and this 'should put to rest the old argument that RF radiation cannot cause DNA damage'. The study is currently under peer review.

These new NTP study results appear to corroborate the findings of the 1995 study by Lai and Singh regarding increased levels of DNA single-strand breaks in brain cells from rats acutely exposed to low-intensity $2,450 \mathrm{MHz}$ microwaves (21). A dose-rate-dependent increase in DNA single-strand breaks was found in brain cells of rats at $4 \mathrm{~h}$ post-exposure to 0.6 and $1.2 \mathrm{~W} / \mathrm{kg}$ whole-body SAR. In rats exposed for $2 \mathrm{~h}$ to continuous-wave 2,450 MHz microwaves (SAR $1.2 \mathrm{~W} / \mathrm{kg}$ ), increases in brain cell DNA single-strand breaks were observed immediately as well as at $4 \mathrm{~h}$ post-exposure (21).

Our research group published the first results on the increased risk for brain tumours associated with the use of mobile and cordless phones $\sim 15$ years ago (22-25). More results have been obtained from our subsequent studies, as well as from studies conducted in other countries. The International Agency for Research on Cancer (IARC) at WHO concluded in 2011 that RF radiation is a possible human carcinogen, Group 2B $(26,27)$. The IARC decision was based on human Swedish studies by our group (28-30) and the IARC Interphone Study (31-33) giving evidence of increased risk for brain tumours, mainly glioma, and acoustic neuroma in subjects using mobile phones. These results have been replicated in our subsequent studies (34-37) and the French CERENAT study on glioma and meningioma (38). IARC concluded that there is limited evidence from experimental animal studies supporting the carcinogenicity of RF radiation. However, later published human and animal studies reported that there is sufficient evidence of the carcinogenicity of RF radiation. That conclusion is supported by our review (39) using the Bradford Hill viewpoints (40) on the association or causation on environment and disease. Mechanistic studies that support a causal inference are also currently available and discussed below.

As areas with high RF radiation were previously recorded at the Stockholm Central Station in Sweden (1), the aim of the present study was to continue with outdoor measurements in locations visited by numerous individuals in Stockholm. Stockholm Old Town is a popular place for tourists that is located in Stockholm City within walking distance from the Central Railway Station. Several people reside in the Old Town and a number of shops and restaurants are located within this area. In addition, certain government buildings, such as the Supreme Court and the Royal Castle and the nearby Swedish Parliament, are located in that region as well.

As this was a measurement study with no involvement of test subjects, no ethical permission was required.

\section{Materials and methods}

EME Spy 200 exposimeter. In this study, an EME Spy 200 exposimeter (Satimo, MVG Industries, Brest, France) with a valid calibration was used to collect the exposure data. The exposimeter measures 20 predefined frequency bands, as presented in Table I. These cover the frequencies of most public RF radiation emitting devices currently used in Sweden. The exposimeter covers frequencies of $87-5,850 \mathrm{MHz}$. For frequency modulation (FM), TV3, TETRA, TV4\&5, Wi-Fi $2 \mathrm{G}$ and Wi-Fi $5 \mathrm{G}$, the lower detection limit is $0.01 \mathrm{~V} / \mathrm{m}$ $\left(0.27 \mu \mathrm{W} / \mathrm{m}^{2}\right)$; for all other bands, the lower detection limit is $0.005 \mathrm{~V} / \mathrm{m}\left(0.066 \mu \mathrm{W} / \mathrm{m}^{2}\right)$. For all bands, the upper detection limit is $6 \mathrm{~V} / \mathrm{m}\left(95,544 \mu \mathrm{W} / \mathrm{m}^{2}\right.$; $\left.9.5544 \mu \mathrm{W} / \mathrm{cm}^{2}\right)$. The sampling time used in this study was every 4 th sec, which is the fastest for the given exposimeter.

The exposimeter measures different telecommunications protocols: FM radio broadcasting; TV broadcasting; TETRA emergency services (police, rescue, etc.); GSM second-generation mobile communications; UMTS third-generation mobile communications, 3G; long-term evolution (LTE) fourth-generation mobile communications standard, 4G; digital European cordless telecommunications (DECT) cordless telephone systems standard; Wi-Fi wireless local area network protocol; worldwide interoperability for microwave access (WiMAX) wireless communication standard for high-speed voice, data and internet.

EME SPY 200 utilizes 3-axis antennas to capture RF radiation from all possible directions. The exposimeter was held at a distance of $\sim 0.4 \mathrm{~m}$ from the body. The unit reports the exposure in a conservative manner, since each reported value is the sampling outcome, where many samples are collected and statistically processed including minimum, mean, median and maximum values.

Study design. The study was performed during daytime in April 8, 9, 10, 11, 13 and 22, 2016. These were all business days, except for April 9 and 10 (Saturday and Sunday). The length of the measurement route was up to $2.5 \mathrm{~h}$, depending on the investigation. All major streets were covered during the investigation rounds. A few very short and narrow streets were not included. In addition, special measurement rounds were made using the streets surrounding the Supreme Court and the Royal Castle. The Swedish Parliament was also measured using the streets surrounding the Parliament as well as the central street, Riksgatan. Special measurement rounds were made at three squares, Stortorget, Kornhamnstorg and Järntorget. All measurements were included in the total result for the Old Town, except for the Swedish Parliament, which is located on the island of Helgeandsholmen and is reported separately. The buildings were selected as they are important sites 
for decision-makers in Sweden. The squares were included as they are frequented by numerous visitors sitting outdoors at the restaurants and cafés. The selected locations as major streets, squares and buildings were measured several times, whereas small streets were measured only once. It should be noted that the Old Town is located on an island surrounded by water and, thus, is geographically well-defined (Fig. 1).

Statistical methods. Means, medians, minimum and maximum values in $\mu \mathrm{W} / \mathrm{m}^{2}$ were calculated for all measured frequency bands and for total exposure, and box plots were constructed to illustrate the distribution of total exposure for all measurement rounds. Values below the lower detection limit were treated as null (0). Total exposure was calculated as the sum of all measured frequency bands at each measured data point. Stata/ SE 12.1 for Windows (StataCorp., College Station, TX, USA) was used for all calculations.

\section{Results}

The results of the Old Town measurements were based on 10,437 measurements in total during five separate measurement rounds, with a total of 696 min of measurements $(\sim 12 \mathrm{~h})$. The results are displayed in Table II. The mean total level of $\mathrm{RF}$ radiation was $4,292.7 \mu \mathrm{W} / \mathrm{m}^{2}$. The highest mean values were obtained for GSM + UMTS 900 downlink and LTE 2600 downlink (1,558.2 and 1,264.9 $\mu \mathrm{W} / \mathrm{m}^{2}$, respectively). It should be noted that the highest maximum levels were from base stations (5 bands) varying from 24,384.7 (LTE 800 downlink) to $95,522.5$ (LTE 2600 downlink) $\mu \mathrm{W} / \mathrm{m}^{2}$. The highest maximum uplink (from a mobile phone) was found for GSM 1800, yielding 19,136.9 $\mu \mathrm{W} / \mathrm{m}^{2}$.

In Fig. 2, the box plot shows the results for five old town measurements and all exposure (total). The total median level was $534.0 \mu \mathrm{W} / \mathrm{m}^{2}$ with several outliers of $>100,000 \mu \mathrm{W} / \mathrm{m}^{2}$.

In Fig. 3. the RF exposure variation over time is displayed for one of the measurement rounds. There was a large variation over time during these $>2 \mathrm{~h}$ measurements covering major parts of the Old Town (streets and squares). The mean level was $5,371.4 \mu \mathrm{W} / \mathrm{m}^{2}$ (median, $701.8 \mu \mathrm{W} / \mathrm{m}^{2}$; range, 4.2-83,348.8 $\mu \mathrm{W} / \mathrm{m}^{2}$ ). Only for few moments the exposure was $<100 \mu \mathrm{W} / \mathrm{m}^{2}$, whereas several measurements were $>10,000 \mu \mathrm{W} / \mathrm{m}^{2}$.

Royal castle. The Swedish Royal Castle was covered by measurement rounds on the surrounding streets and also the Castle Square (Yttre Borggården) during 4 h measurement time in total. These measurements represent an area with among the lowest RF radiation in the Old Town. The results were also included in the total measurement of the Old Town. Rather low mean values were found for most downlink bands (Table III). The highest mean level was measured for UMTS 2100 downlink $\left(306.2 \mu \mathrm{W} / \mathrm{m}^{2}\right)$. The total mean $\mathrm{RF}$ radiation level for the Royal Castle area was $755.6 \mu \mathrm{W} / \mathrm{m}^{2}$, representing only $17.6 \%$ of the total mean level for the Old Town. In addition, the total highest level (maximum) was lower than all $\left(50,967.1 \mu \mathrm{W} / \mathrm{m}^{2}\right.$, or $29.4 \%$ of the total).

The box plot in Fig. 4 of the six measurement tours to the Royal Castle area and total clearly shows lower levels compared with those for all the Old Town. The total median
Table I. Frequency ranges of predefined measurement frequency bands of EME Spy 200 exposimeter.

\begin{tabular}{lcc}
\hline Frequency band & $\begin{array}{c}\text { Frequency } \\
\text { min }(\mathrm{MHz})\end{array}$ & $\begin{array}{c}\text { Frequency } \\
\max (\mathrm{MHz})\end{array}$ \\
\hline FM & 87 & 107 \\
TV3 & 174 & 223 \\
TETRA I & 380 & 400 \\
TETRA II & 410 & 430 \\
TETRA III & 450 & 470 \\
TV4\&5 & 470 & 770 \\
LTE 800, 4G (DL) & 791 & 821 \\
LTE 800, 4G (UL) & 832 & 862 \\
GSM 900 + UMTS 900, 3G (UL) & 880 & 915 \\
GSM 900 + UMTS 900, 3G (DL) & 925 & 960 \\
GSM 1800 (UL) & 1,710 & 1,785 \\
GSM 1800 (DL) & 1,805 & 1,880 \\
DECT & 1,880 & 1,900 \\
UMTS 2100, 3G (UL) & 1,920 & 1,980 \\
UMTS 2100, 3G (DL) & 2,110 & 2,170 \\
Wi-Fi 2 GHz & 2,400 & $2,483.5$ \\
LTE 2600, 4G (UL) & 2,500 & 2,570 \\
LTE 2600, 4G (DL) & 2,620 & 2,690 \\
WiMAX & 3,300 & 3,900 \\
Wi-Fi 5 GHz & 5,150 & 5,850 \\
\end{tabular}

FM, frequency modulation; TV, television; LTE, long-term evolution; DL, downlink (transmission from base station to mobile phone); UL, uplink (transmission from mobile phone to base station); GSM, global system for mobile communications; UMTS, universal mobile telecommunications system; DECT, digital European cordless telecommunications; WiMAX, worldwide interoperability for microwave access.

level was $387.8 \mu \mathrm{W} / \mathrm{m}^{2}$, without any significant variation between different tours.

Fig. 5 shows the RF exposure variation over time during one of the measurement rounds around the Royal Castle, clearly indicating that most measurements were $<1,000 \mu \mathrm{W} / \mathrm{m}^{2}$, with few spikes exceeding $10,000 \mu \mathrm{W} / \mathrm{m}^{2}$.

Supreme court. The results for the Supreme Court are displayed in Table IV. These measurements represent the lowest levels of $\mathrm{RF}$ radiation among all measurements. The total mean level was $403.6 \mu \mathrm{W} / \mathrm{m}^{2}$ and the maximum level was $4,088.1 \mu \mathrm{W} / \mathrm{m}^{2}$. Almost all exposure represented downlink bands from mobile telephony base stations.

Fig. 6 displays the box plot for the measurement tours around the Supreme Court and all exposure (total). The total median level was $274.5 \mu \mathrm{W} / \mathrm{m}^{2}$. Total exposure over time during the tours exhibited little difference over time, mostly $<1,000 \mu \mathrm{W} / \mathrm{m}^{2}$. The time variation for one tour is shown in Fig. 7.

Old town squares. The mean values for three major squares in the Old Town are shown in Table V. Several shops, restaurants and cafés are located in this region, including outdoor sitting 


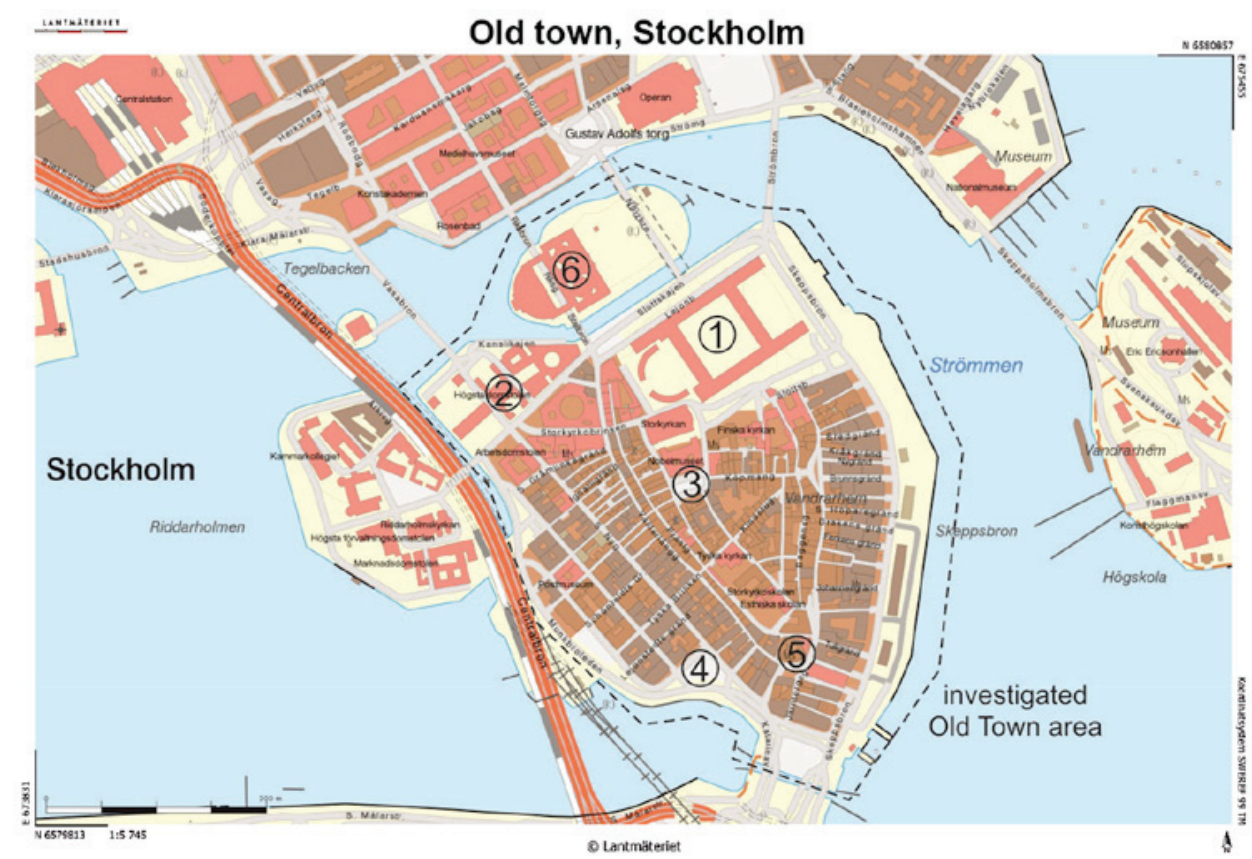

Figure 1. Map of Stockholm Old Town and Helgeandsholmen. Specific measurement locations are shown as follows: 1, Royal Castle; 2, Supreme Court; 3, Stortorget; 4, Kornhamnstorg; 5, Järntorget and 6, Swedish Parliament. Map from Lantmäteriet, Sweden.

areas. The results represent the highest measurements in the Old Town.

The highest levels were measured at the Järntorget square, as presented in Table VI. Only at Järntorget some levels for FM radio were detected, which were comparatively low in other parts of the Old Town. Very high mean and maximum levels were found for all downlinks from mobile telephony base stations, except for GSM 1800. The mean level for GSM + UMTS 900 downlink was noteworthy $\left(10,272.7 \mu \mathrm{W} / \mathrm{m}^{2}\right)$. An exceptionally high total maximum level of $95,522.5 \mu \mathrm{W} / \mathrm{m}^{2}$ was measured for LTE 2600 downlink.

The box plot for the measurements in Järntorget is shown in Fig. 8 and variation over time during one tour is shown in Fig. 9. High levels were measured, with a total median of $19,990.0 \mu \mathrm{W} / \mathrm{m}^{2}$.

Swedish parliament. The Swedish Parliament is located on a separate island, Helgeandsholmen, just outside the Old Town. The results of four measurement rounds of $\sim 1.5 \mathrm{~h}$ measurement time in total are shown in Table VII. Significantly lower levels were found compared with total measurements for the Old Town. RF level dynamics for one measurement tour are seen in Fig. 10.

Old town summary. The box plot in Fig. 11 shows a large variation in total exposure across measured sites in Stockholm Old Town. Relatively low RF levels were measured at the Royal Castle and the Supreme Court, whereas the Stortorget, Kornhamnstorg and Järntorget squares had exposure levels of at least an order of magnitude higher.

\section{Discussion}

The Stockholm Old Town RF radiation levels were measured on five occasions, yielding a total of 10,437 readings for the
Old Town. This study showed a large variation in outdoor RF radiation level in the Stockholm Old Town. Furthermore, it should be noted that the measurements mainly characterize downlink exposure, without considering personal use of wireless devices, such as mobile phones. Indoor RF levels are likely to be somewhat lower with respect to inbound radiation, since the walls and windows of buildings attenuate the signals. On the other hand, on the premises on the opposite side of the transmitter antennas, the exposure levels may be even an order of magnitude higher if the beam happens to be directed towards these premises. For accurate information it would be necessary to make measurements inside buildings such as the Royal Castle, the Supreme Court, restaurants, apartments and the Swedish Parliament. Several buildings contain Wi-Fi routers for wireless communication, which would increase exposure at Wi-Fi bands. Furthermore, personal use of wireless phones (mobile as well as cordless), use of tablets and wireless internet via computers, add to RF radiation exposure.

This study provides information on the passive RF radiation exposure in a popular area of Stockholm, which is a destination for a number of visitors, such as tourists, citizens contacting different authorities, employees and residents. The study determined low levels at the surroundings of the Royal Castle, with a mean level of $755.6 \mu \mathrm{W} / \mathrm{m}^{2}$, which is $17.6 \%$ of the total mean level in the Old Town $\left(4,292.7 \mu \mathrm{W} / \mathrm{m}^{2}\right)$. An even lower mean level was measured for the Supreme Court $(403.6 \mu \mathrm{W} / \mathrm{m})$, representing $9.4 \%$ of the total mean level for the Old Town. It should also be noted that certain hotspots had somewhat higher RF radiation levels, both for the Royal Castle and the Supreme Court (Figs. 5 and 7). This is also illustrated by the box plots (Figs. 4 and 6) with third quartiles of $<1,000 \mu \mathrm{W} / \mathrm{m}^{2}$, with the exception of one of the Royal Castle measurements.

The abovementioned results are in large contrast to the squares of the Old Town. The three major squares were 
Table II. Stockholm Old Town levels of radiofrequency radiation in total for five different tours on 8, 9, 11, 13 and 22 April, 2016.

\begin{tabular}{|c|c|c|c|c|c|}
\hline Frequency band & No. of readings & Mean & Median & Min & Max \\
\hline FM & 10,437 & 11.1 & 0.0 & 0.0 & $3,674.6$ \\
\hline TV3 & 10,437 & 1.5 & 0.0 & 0.0 & 273.3 \\
\hline TETRA I & 10,437 & 18.6 & 0.0 & 0.0 & $2,913.3$ \\
\hline TETRA II & 10,437 & 0.2 & 0.0 & 0.0 & 253.3 \\
\hline TETRA III & 10,437 & 0.6 & 0.0 & 0.0 & 790.8 \\
\hline TV4\&5 & 10,437 & 4.0 & 0.0 & 0.0 & $2,775$. \\
\hline LTE 800 (DL) & 10,437 & 473.6 & 9.5 & 0.0 & $24,384.7$ \\
\hline LTE 800 (UL) & 10,437 & 0.0 & 0.0 & 0.0 & 1.7 \\
\hline GSM + UMTS 900 (UL) & 10,437 & 4.3 & 0.0 & 0.0 & $9,972.7$ \\
\hline GSM + UMTS 900 (DL) & 10,437 & $1,558.2$ & 38.2 & 0.0 & $84,495.3$ \\
\hline GSM 1800 (UL) & 10,437 & 10.3 & 1.0 & 0.0 & $19,136$. \\
\hline GSM 1800 (DL) & 10,437 & 215.2 & 37.6 & 0.0 & $73,221.5$ \\
\hline DECT & 10,437 & 5.0 & 0.0 & 0.0 & $1,127.6$ \\
\hline UMTS 2100 (UL) & 10,437 & 0.0 & 0.0 & 0.0 & 51.2 \\
\hline UMTS 2100 (DL) & 10,437 & 720.4 & 152.8 & 0.0 & $71,228.5$ \\
\hline Wi-Fi 2G & 10,437 & 0.4 & 0.0 & 0.0 & 288.9 \\
\hline LTE 2600 (UL) & 10,437 & 4.6 & 0.0 & 0.0 & $3,832$. \\
\hline LTE 2600 (DL) & 10,437 & $1,264.9$ & 84.0 & 0.0 & $95,522.5$ \\
\hline WiMAX & 10,437 & 0.0 & 0.0 & 0.0 & 3.1 \\
\hline Wi-Fi 5G & 10,437 & 0.0 & 0.0 & 0.0 & 62.1 \\
\hline Total & 10,437 & $4,292.7$ & 534.0 & 0.0 & $173,301.8$ \\
\hline
\end{tabular}

Analysis of all data $\left(\mu \mathrm{W} / \mathrm{m}^{2}\right)$ treating values at detection limit as $0 . \mathrm{FM}$, frequency modulation; TV, television; LTE, long-term evolution; DL, downlink (transmission from base station to mobile phone); UL, uplink (transmission from mobile phone to base station); GSM, global system for mobile communications; UMTS, universal mobile telecommunications system; DECT, digital European cordless telecommunications; WiMAX, worldwide interoperability for microwave access.

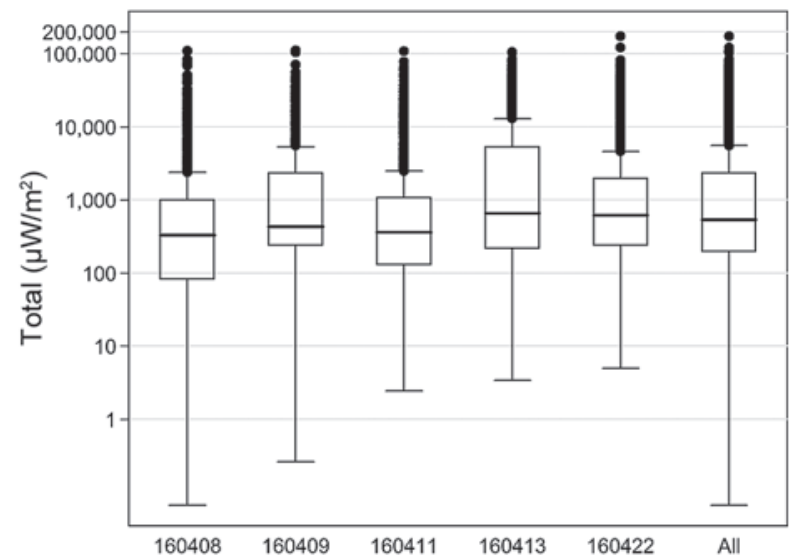

Figure 2. Stockholm Old Town. Box plot for exposure in $\mu \mathrm{W} / \mathrm{m}^{2}$, logarithmic scale, for the five measurement rounds and total exposure. The median is indicated by the black line inside each box; the bottom and top of the boxes represent the first and third quartiles; the end of the whiskers are calculated as $1.5 \mathrm{x}$ interquartile range. The points represent the outliers.

measured, namely Stortorget in the area of the Royal Castle, Kornhamnstorg and Järntorget at the other end of the Old Town. Particularly striking is the RF radiation level at Järntorget, although high mean levels were measured in all squares.

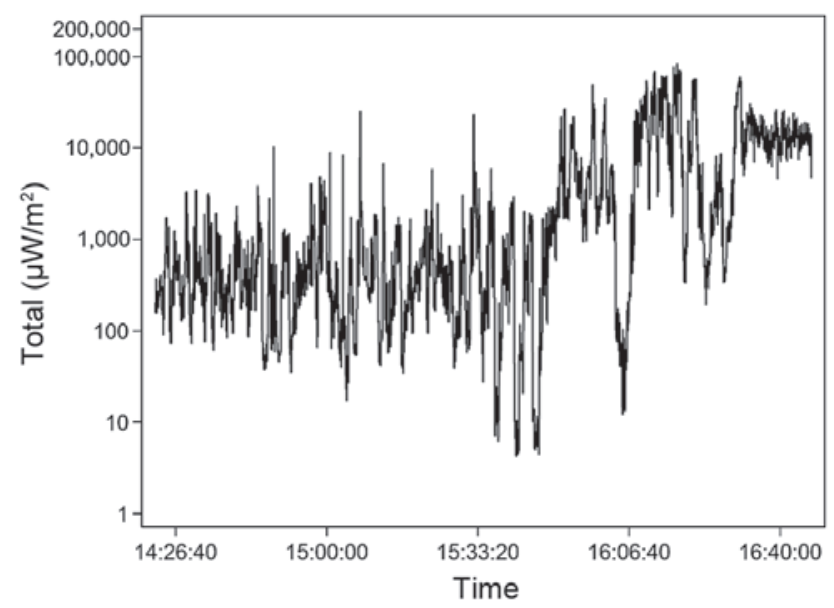

Figure 3. Stockholm Old Town. Total radiofrequency field exposure (mean exposure, 5,371.4 $\mu \mathrm{W} / \mathrm{m}^{2}$, logarithmic scale) over time of one typical exposure round (13 April, 2016; time, 14:22:14-16:46:58).

The mean RF radiation level at Järntorget was $24,277.1 \mu \mathrm{W} / \mathrm{m}^{2}$, which is 60 times higher compared with that for the Supreme Court. It should also be noted that the maximum level for Järntorget was $173,301.8 \mu \mathrm{W} / \mathrm{m}^{2}$, compared with $4,088.1 \mu \mathrm{W} / \mathrm{m}^{2}$ for the Supreme Court, which is 42 times higher. 
Table III. Stockholm Royal Castle levels of radiofrequency radiation in total as measured on 9, 11, 13 and 22 April, 2016.

\begin{tabular}{|c|c|c|c|c|c|}
\hline Frequency band & No. of readings & Mean & Median & Min & Max \\
\hline FM & 3,385 & 3.7 & 0.9 & 0.0 & 140.3 \\
\hline TV3 & 3,385 & 1.8 & 0.0 & 0.0 & 85.9 \\
\hline TETRA I & 3,385 & 51.6 & 1.7 & 0.0 & $2,913.3$ \\
\hline TETRA II & 3,385 & 0.3 & 0.0 & 0.0 & 74.9 \\
\hline TETRA III & 3,385 & 0.8 & 0.0 & 0.0 & 655.2 \\
\hline TV4\&5 & 3,385 & 1.4 & 0.0 & 0.0 & 133.1 \\
\hline LTE 800 (DL) & 3,385 & 19.3 & 2.4 & 0.0 & 492.7 \\
\hline LTE 800 (UL) & 3,385 & 0.0 & 0.0 & 0.0 & 0.3 \\
\hline GSM + UMTS 900 (UL) & 3,385 & 9.7 & 0.0 & 0.0 & $9,972.7$ \\
\hline GSM + UMTS 900 (DL) & 3,385 & 51.2 & 6.6 & 0.0 & $3,961.0$ \\
\hline GSM $1800(\mathrm{UL})$ & 3,385 & 14.4 & 1.2 & 0.0 & $19,136.9$ \\
\hline GSM 1800 (DL) & 3,385 & 172.4 & 42.1 & 0.0 & $44,198.2$ \\
\hline DECT & 3,385 & 1.4 & 0.0 & 0.0 & 234.0 \\
\hline UMTS 2100 (UL) & 3,385 & 0.0 & 0.0 & 0.0 & 51.2 \\
\hline UMTS 2100 (DL) & 3,385 & 306.2 & 126.1 & 0.1 & $32,530.5$ \\
\hline Wi-Fi 2G & 3,385 & 0.1 & 0.0 & 0.0 & 26.0 \\
\hline LTE 2600 (UL) & 3,385 & 0.7 & 0.0 & 0.0 & 60.5 \\
\hline LTE 2600 (DL) & 3,385 & 120.6 & 40.8 & 0.0 & $6,909.8$ \\
\hline WiMAX & 3,385 & 0.0 & 0.0 & 0.0 & 0.0 \\
\hline Wi-Fi 5G & 3,385 & 0.0 & 0.0 & 0.0 & 1.4 \\
\hline Total & 3,385 & 755.6 & 387.8 & 0.3 & $50,967.1$ \\
\hline
\end{tabular}

Analysis of all data $\left(\mu \mathrm{W} / \mathrm{m}^{2}\right)$ treating values at detection limit as $0 . \mathrm{FM}$, frequency modulation; TV, television; LTE, long-term evolution; DL, downlink (transmission from base station to mobile phone); UL, uplink (transmission from mobile phone to base station); GSM, global system for mobile communications; UMTS, universal mobile telecommunications system; DECT, digital European cordless telecommunications; WiMAX, worldwide interoperability for microwave access.

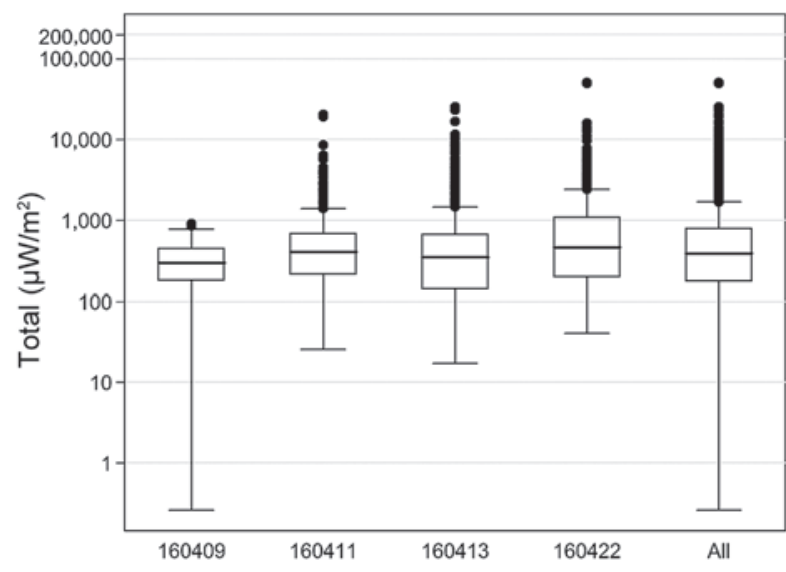

Figure 4. Stockholm Royal Castle. Box plot for exposure in $\mu \mathrm{W} / \mathrm{m}^{2}$, logarithmic scale, for four measurement rounds and total exposure. The median is indicated by the black line inside each box; the bottom and top of the boxes represent the first and third quartiles; the end of the whiskers are calculated as $1.5 \mathrm{x}$ interquartile range. The points represent the outliers.

The high RF radiation exposure at the squares is of major concern due to the numerous shops, outdoor restaurants and cafés. The measured RF radiation is almost exclusively from mobile telephony base stations (e.g., see Table VI for Järntorget). Some of the base stations appear to be located

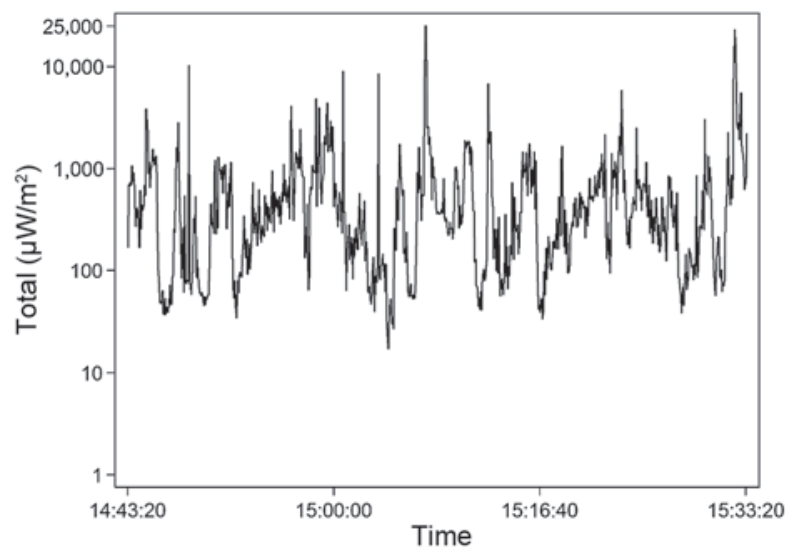

Figure 5. Stockholm Royal Castle. Total radiofrequency field exposure (mean exposure, $721.2 \mu \mathrm{W} / \mathrm{m}^{2}$, logarithmic scale) over time of one typical exposure round (13 April, 2016; time, 14:43:22-15:33:26).

in buildings of rather low height, with the radiation directed towards the sitting area of restaurants and coffee shops. The location of a base station at one of the measured squares is shown in Fig. 12; it was placed rather low, with the main emission directed towards an outdoor restaurant at a short distance.

Our results are significantly lower compared with the ICNIRP exposure guideline of $10,000,000 \mu \mathrm{W} / \mathrm{m}^{2}$. However, 
Table IV. Stockholm Supreme Court levels of radiofrequency radiation in total, as measured on 13 and 22 April, 2016.

\begin{tabular}{|c|c|c|c|c|c|}
\hline Frequency band & No. of readings & Mean & Median & Min & Max \\
\hline FM & 715 & 0.6 & 0.0 & 0.0 & 29.2 \\
\hline TV3 & 715 & 1.2 & 0.0 & 0.0 & 35.7 \\
\hline TETRA I & 715 & 0.3 & 0.0 & 0.0 & 58.9 \\
\hline TETRA II & 715 & 0.3 & 0.0 & 0.0 & 12.6 \\
\hline TETRA III & 715 & 0.1 & 0.0 & 0.0 & 26.0 \\
\hline TV4\&5 & 715 & 0.1 & 0.0 & 0.0 & 19.2 \\
\hline LTE 800 (DL) & 715 & 18.4 & 4.7 & 0.1 & 898.5 \\
\hline LTE 800 (UL) & 715 & 0.0 & 0.0 & 0.0 & 0.0 \\
\hline GSM + UMTS $900(\mathrm{UL})$ & 715 & 6.1 & 0.0 & 0.0 & $2,874.5$ \\
\hline GSM + UMTS 900 (DL) & 715 & 32.7 & 11.2 & 0.2 & 578.5 \\
\hline GSM 1800 (UL) & 715 & 4.7 & 2.5 & 0.0 & 65.4 \\
\hline GSM 1800 (DL) & 715 & 104.6 & 54.2 & 3.4 & $2,196.6$ \\
\hline DECT & 715 & 0.0 & 0.0 & 0.0 & 1.1 \\
\hline UMTS 2100 (UL) & 715 & 0.0 & 0.0 & 0.0 & 0.3 \\
\hline UMTS 2100 (DL) & 715 & 82.0 & 46.2 & 0.4 & $1,966.4$ \\
\hline Wi-Fi $2 \mathrm{G}$ & 715 & 0.1 & 0.0 & 0.0 & 8.3 \\
\hline LTE 2600 (UL) & 715 & 0.1 & 0.0 & 0.0 & 4.5 \\
\hline LTE 2600 (DL) & 715 & 152.3 & 87.9 & 3.8 & $3,674.6$ \\
\hline WiMAX & 715 & 0.0 & 0.0 & 0.0 & 0.0 \\
\hline Wi-Fi 5G & 715 & 0.0 & 0.0 & 0.0 & 0.9 \\
\hline Total & 715 & 403.6 & 274.5 & 20.4 & $4,088.1$ \\
\hline
\end{tabular}

Analysis of all data $\left(\mu \mathrm{W} / \mathrm{m}^{2}\right)$ treating values at detection limit as $0 . \mathrm{FM}$, frequency modulation; TV, television; LTE, long-term evolution; DL, downlink (transmission from base station to mobile phone); UL, uplink (transmission from mobile phone to base station); GSM, global system for mobile communications; UMTS, universal mobile telecommunications system; DECT, digital European cordless telecommunications; WiMAX, worldwide interoperability for microwave access.

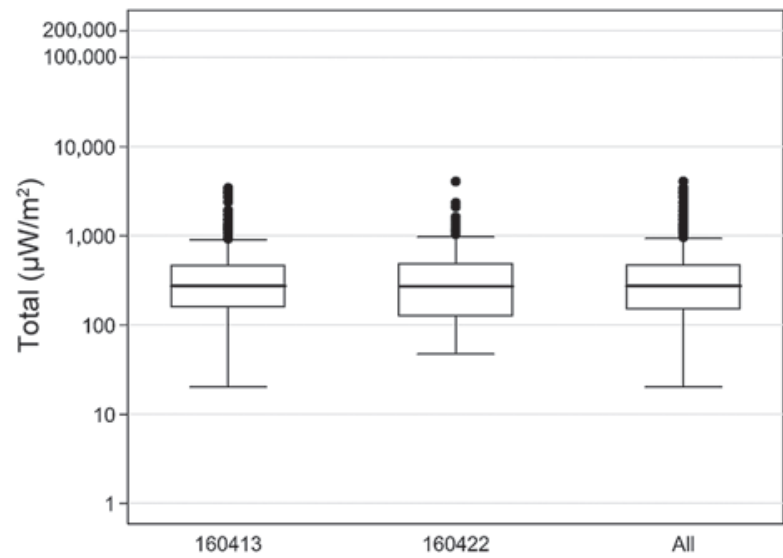

Figure 6. Stockholm Supreme Court. Box plot for exposure in $\mu \mathrm{W} / \mathrm{m}^{2}$, logarithmic scale, for two measurement rounds and total exposure. The median is indicated by the black line inside each box; the bottom and top of the boxes represent the first and third quartiles; the end of the whiskers are calculated as $1.5 \mathrm{x}$ interquartile range. The points represent the outliers.

that guideline is outdated, since it does not include current scientific findings in humans and laboratory studies on RF radiation exposure. On the other hand, most measurements were higher than the scientific benchmark of 30-60 $\mu \mathrm{W} / \mathrm{m}^{2}$ that has been proposed to be the lowest observed effect level

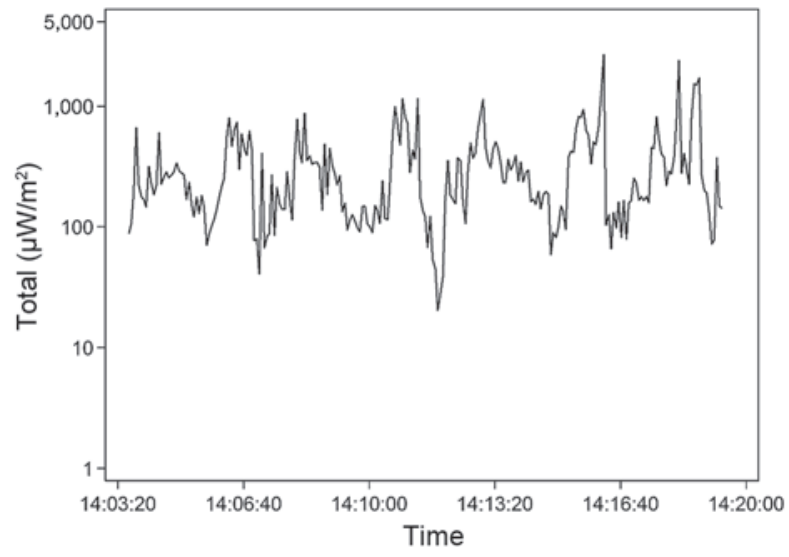

Figure 7. Stockholm Supreme Court. Total radiofrequency field exposure (mean exposure, $335.6 \mu \mathrm{W} / \mathrm{m}^{2}$, logarithmic scale) over time of one typical exposure round (13 April, 2016; time, 14:03:37-14:19:21).

for RF radiation in Chapter 24 of the BioInitiative Report (6). Furthermore, our result on a total mean RF radiation level of 4,292.7 $\mu \mathrm{W} / \mathrm{m}^{2}$ in the Old Town (Table II) is of major concern, considering the oxidative effects on living cells from exposure to a level of RF radiation as low as $2,500 \mu \mathrm{W} /$ $\mathrm{m}^{2}$, as described by Yakymenko et al (41). This is also of 
Table V. Stockholm Old Town mean levels of radiofrequency radiation $\left(\mu \mathrm{W} / \mathrm{m}^{2}\right)$ for three squares, treating values at detection limit as 0 .

\begin{tabular}{|c|c|c|c|c|c|c|}
\hline \multirow[b]{2}{*}{ Frequency band } & \multicolumn{2}{|c|}{$\begin{array}{c}\text { Stortorget, } \\
\text { April } 13 \text { and 22, } 2016\end{array}$} & \multicolumn{2}{|c|}{$\begin{array}{c}\text { Kornhamnstorg, } \\
\text { April } 13 \text { and 22, } 2016\end{array}$} & \multicolumn{2}{|c|}{$\begin{array}{c}\text { Järntorget, April 11, } \\
13 \text { and 22, } 2016\end{array}$} \\
\hline & No. ${ }^{a}$ & Mean & No. ${ }^{a}$ & Mean & No. ${ }^{a}$ & Mean \\
\hline FM & 527 & 2.8 & 1,191 & 24.4 & 574 & 67.9 \\
\hline TV3 & 527 & 0.0 & 1,191 & 0.4 & 574 & 0.7 \\
\hline TETRA I & 527 & 0.6 & 1,191 & 0.0 & 574 & 0.9 \\
\hline TETRA II & 527 & 0.0 & 1,191 & 0.3 & 574 & 0.0 \\
\hline TETRA III & 527 & 0.1 & 1,191 & 0.0 & 574 & 0.4 \\
\hline TV4\&5 & 527 & 4.3 & 1,191 & 3.4 & 574 & 30.8 \\
\hline LTE 800 (DL) & 527 & 863.0 & 1,191 & $1,762.6$ & 574 & $2,917.6$ \\
\hline LTE 800 (UL) & 527 & 0.0 & 1,191 & 0.0 & 574 & 0.0 \\
\hline GSM + UMTS 900 (UL) & 527 & 0.0 & 1,191 & 0.0 & 574 & 0.0 \\
\hline GSM + UMTS 900 (DL) & 527 & $2,721.9$ & 1,191 & $5,222.3$ & 574 & $10,272.7$ \\
\hline GSM $1800(\mathrm{UL})$ & 527 & 10.8 & 1,191 & 7.5 & 574 & 0.1 \\
\hline GSM 1800 (DL) & 527 & 194.4 & 1,191 & 590.8 & 574 & 12.1 \\
\hline DECT & 527 & 0.0 & 1,191 & 39.2 & 574 & 0.0 \\
\hline UMTS 2100 (UL) & 527 & 0.0 & 1,191 & 0.0 & 574 & 0.0 \\
\hline UMTS 2100 (DL) & 527 & $1,811.0$ & 1,191 & 672.2 & 574 & $4,049.7$ \\
\hline Wi-Fi 2G & 527 & 0.1 & 1,191 & 2.2 & 574 & 0.3 \\
\hline LTE 2600 (UL) & 527 & 2.7 & 1,191 & 0.0 & 574 & 0.8 \\
\hline LTE 2600 (DL) & 527 & $3,441.8$ & 1,191 & $3,677.1$ & 574 & $6,923.0$ \\
\hline WiMAX & 527 & 0.0 & 1,191 & 0.0 & 574 & 0.0 \\
\hline Wi-Fi 5G & 527 & 0.0 & 1,191 & 0.1 & 574 & 0.0 \\
\hline Total & 527 & $9,053.7$ & 1,191 & $12,002.6$ & 574 & $24,277.1$ \\
\hline
\end{tabular}

${ }^{a}$ Number of readings. FM, frequency modulation; TV, television; LTE, long-term evolution; DL, downlink (transmission from base station to mobile phone); UL, uplink (transmission from mobile phone to base station); GSM, global system for mobile communications; UMTS, universal mobile telecommunications system; DECT, digital European cordless telecommunications; WiMAX, worldwide interoperability for microwave access.

concern, since reactive oxidative species are crucial in carcinogenesis.

In Sweden, the dominating sources are currently exposure from mobile communication with UMTS, 3G and LTE, 4G with addition of Wi-Fi indoors, but also in certain outdoors locations. Our study from Stockholm Central Railway Station in 2015 yielded a mean total radiation level of $2,817-4,891 \mu \mathrm{W} / \mathrm{m}^{2}$ for each measurement round and a median value of $921 \mu \mathrm{W} / \mathrm{m}^{2}$ for all rounds. The mean for all rounds was $3,860 \mu \mathrm{W} / \mathrm{m}^{2}$. In addition, hotspots were registered yielding $>95,544 \mu \mathrm{W} / \mathrm{m}^{2}$, which exceeded the exposimeter EME-Spy 200 's upper detection limit. GSM+UMTS 900 downlink and UMTS 2100 downlink contributed the most, but LTE 800 downlink, GSM 1800 downlink and LTE 2600 downlink were also in the higher range of measurements (1). Thus, these results are similar to those of the present study.

The results of the present study show a large variation in passive outdoor RF radiation exposure in Stockholm Old Town. One explanation may be that there are no outdoor places with sitting areas to accommodate people during lunch or coffee breaks around the Royal Castle or the Supreme Court.
This also applies to the Swedish Parliament, which is located on a separate island close to the Old Town. Thus, base stations are located around the squares to enable good network access. However, a lower level of radiation would still enable good network access (6). Comparatively low levels of RF radiation were measured for the Swedish Parliament compared with Järntorget. However, no indoor measurements were performed at the Swedish Parliament, where the RF radiation level would be quite different due to wireless internet access within the Parliament.

Unlike in other city districts, where mobile phone base station antennas are placed at a certain height, in the Old Town some antennas are located significantly closer to humans, sometimes only a few meters from the ground level. This creates areas of significantly high RF radiation, particularly in the immediate vicinity of such antennas. The exposure situation is worsened by the narrow streets and tall walls, which tend to trap the radio waves, hence creating reflections and increasing the exposure. The highest radiation zones may be proposed at buildings with windows facing the mobile base station antenna just across the street at the same height. The 
Table VI. Järntorget mean levels of radiofrequency radiation $\left(\mu \mathrm{W} / \mathrm{m}^{2}\right)$ on 11,13 and 22 April, 2016, treating values at detection limit as 0 .

\begin{tabular}{|c|c|c|c|c|c|}
\hline Frequency band & No. of readings & Mean & Median & Min & Max \\
\hline FM & 574 & 67.9 & 0.4 & 0.0 & $3,674.6$ \\
\hline TV3 & 574 & 0.7 & 0.0 & 0.0 & 69.6 \\
\hline TETRA I & 574 & 0.9 & 0.0 & 0.0 & 41.4 \\
\hline TETRA II & 574 & 0.0 & 0.0 & 0.0 & 0.7 \\
\hline TETRA III & 574 & 0.4 & 0.0 & 0.0 & 27.1 \\
\hline TV4\&5 & 574 & 30.8 & 0.0 & 0.0 & $2,775.9$ \\
\hline LTE 800 (DL) & 574 & $2,917.6$ & $1,504.0$ & 3.8 & $20,367.2$ \\
\hline LTE 800 (UL) & 574 & 0.0 & 0.0 & 0.0 & 0.0 \\
\hline GSM + UMTS 900 (UL) & 574 & 0.0 & 0.0 & 0.0 & 4.9 \\
\hline GSM + UMTS 900 (DL) & 574 & $10,272.7$ & $6,140.5$ & 29.8 & $65,440.6$ \\
\hline GSM $1800(\mathrm{UL})$ & 574 & 0.1 & 0.0 & 0.0 & 8.9 \\
\hline GSM 1800 (DL) & 574 & 12.1 & 4.5 & 0.6 & 590.9 \\
\hline DECT & 574 & 0.0 & 0.0 & 0.0 & 0.0 \\
\hline UMTS 2100 (UL) & 574 & 0.0 & 0.0 & 0.0 & 2.5 \\
\hline UMTS 2100 (DL) & 574 & $4,049.7$ & $2,716.7$ & 38.2 & $21,078.9$ \\
\hline WIFI 2G & 574 & 0.3 & 0.0 & 0.0 & 25.5 \\
\hline LTE 2600 (UL) & 574 & 0.8 & 0.0 & 0.0 & 35.1 \\
\hline LTE 2600 (DL) & 574 & $6,923.0$ & $4,157.8$ & 30.4 & $95,522.5$ \\
\hline WiMAX & 574 & 0.0 & 0.0 & 0.0 & 3.1 \\
\hline Wi-Fi 5G & 574 & 0.0 & 0.0 & 0.0 & 1.7 \\
\hline Total & 574 & $24,277.1$ & $19,990.0$ & 257.0 & $173,301.8$ \\
\hline
\end{tabular}

FM, frequency modulation; TV, television; LTE, long-term evolution; DL, downlink (transmission from base station to mobile phone); UL, uplink (transmission from mobile phone to base station); GSM, global system for mobile communications; UMTS, universal mobile telecommunications system; DECT, digital European cordless telecommunications; WiMAX, worldwide interoperability for microwave access.

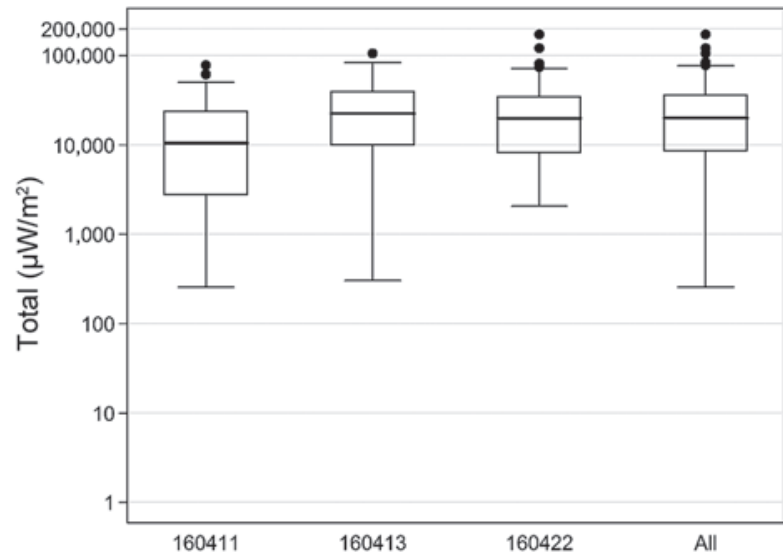

Figure 8. Stockholm Old Town, Järntorget. Box plot for exposure in $\mu \mathrm{W} / \mathrm{m}^{2}$, logarithmic scale, for three measurement rounds and total exposure. The median is indicated by the black line inside each box; the bottom and top of the boxes represent the first and third quartiles; the end of the whiskers are calculated as $1.5 \mathrm{x}$ interquartile range. The points represent the outliers.

most affected are the individuals that have to stay longer in such places, also referred to as hotspots. Individuals whose living quarters, workstation or work area happen to be located in hotspots, are exposed to the heaviest RF load, whereas those

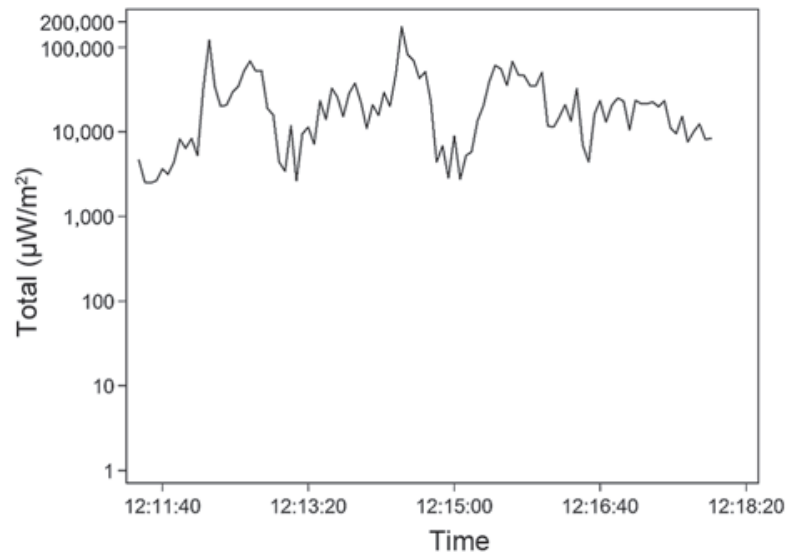

Figure 9. Stockholm Old Town, Järntorget. Total radiofrequency field exposure (mean exposure, 24,766.2 $\mu \mathrm{W} / \mathrm{m}^{2}$, logarithmic scale) over time of one typical exposure round (22 April, 2016; time, 12:11:24-12:17:56).

who walk by hotspots only undergo momentary exposure and are less affected.

As the mobile telephony network is currently under development, the base station antennas are positioned following the current legal safety limits. However, the current limits only provide protection from short-term health effects (heating), but 
Table VII. Stockholm Swedish Parliament mean levels of radiofrequency radiation $\left(\mu \mathrm{W} / \mathrm{m}^{2}\right)$ on $8,10,11$ and 22 April, 2016 , treating values at detection limit as 0 .

\begin{tabular}{|c|c|c|c|c|c|}
\hline Frequency band & No. of readings & Mean & Median & Min & Max \\
\hline FM & 1,196 & 1.7 & 0.0 & 0.0 & 129.6 \\
\hline TV3 & 1,196 & 6.7 & 0.0 & 0.0 & 485.9 \\
\hline TETRA I & 1,196 & 62.8 & 0.4 & 0.0 & $3,157.2$ \\
\hline TETRA II & 1,196 & 2.0 & 0.3 & 0.0 & 52.0 \\
\hline TETRA III & 1,196 & 1.5 & 0.0 & 0.0 & 208.0 \\
\hline TV4\&5 & 1,196 & 0.3 & 0.0 & 0.0 & 50.5 \\
\hline LTE 800 (DL) & 1,196 & 99.7 & 5.9 & 0.0 & $5,623.2$ \\
\hline LTE 800 (UL) & 1,196 & 0.0 & 0.0 & 0.0 & 0.1 \\
\hline GSM + UMTS 900 (UL) & 1,196 & 0.0 & 0.0 & 0.0 & 16.1 \\
\hline GSM + UMTS 900 (DL) & 1,196 & 240.7 & 99.8 & 1.0 & $5,176.7$ \\
\hline GSM $1800(\mathrm{UL})$ & 1,196 & 8.6 & 3.4 & 0.0 & 426.5 \\
\hline GSM 1800 (DL) & 1,196 & 322.6 & 137.9 & 6.1 & $9,395.0$ \\
\hline DECT & 1,196 & 5.5 & 0.0 & 0.0 & 347.6 \\
\hline UMTS 2100 (UL) & 1,196 & 0.0 & 0.0 & 0.0 & 1.5 \\
\hline UMTS 2100 (DL) & 1,196 & 450.7 & 163.1 & 6.4 & $9,717.2$ \\
\hline Wi-Fi $2 \mathrm{G}$ & 1,196 & 0.1 & 0.0 & 0.0 & 8.9 \\
\hline LTE 2600 (UL) & 1,196 & 7.1 & 1.1 & 0.0 & 313.9 \\
\hline LTE 2600 (DL) & 1,196 & 293.9 & 129.6 & 5.1 & $9,385.0$ \\
\hline WiMAX & 1,196 & 0.0 & 0.0 & 0.0 & 0.0 \\
\hline Wi-Fi 5G & 1,196 & 0.0 & 0.0 & 0.0 & 8.9 \\
\hline Total & 1,196 & $1,503.9$ & 957.4 & 99.6 & $16,781.9$ \\
\hline
\end{tabular}

FM, frequency modulation; TV, television; LTE, long-term evolution; DL, downlink (transmission from base station to mobile phone); UL, uplink (transmission from mobile phone to base station); GSM, global system for mobile communications; UMTS, universal mobile telecommunications system; DECT, digital European cordless telecommunications; WiMAX, worldwide interoperability for microwave access.

do not exclude possible long-term effects, which are currently under investigation. To grant better service coverage, the base station antennas are continuously placed in new locations, and the mobile telephony network becomes denser annually. Thus, the RF exposure of the population is increasing, particularly in densely populated areas.

As the research on long-term health hazards is ongoing, it is mostly focused on clearly identifiable biological effects. Knowledge on the effect of RF fields on mental health is of utmost importance, as in chronic exposure to RF radiation levels, such as those measured in hotspots in the Old Town. It should also be noted that long-term health effects, such as cancer, have not been investigated for this type of environmental contamination.

EME Spy 200 is a band-specific exposimeter and it enables identification and measurement of the majority of RF radiation bands currently used in Sweden. This study describes measurements mostly from far-field RF radiation and the exposure that the citizens may undergo without using personal wireless devices. Near-field exposure from personal mobile phones held near the ear or in the hand when on the internet will likely contribute considerably to an individual's total exposure.

The shielding effect from the body of a person carrying an exposimeter may be considerable, as shown by Bolte et al (42) when comparing a body-worn exposimeter with an exposimeter mounted on the roof of a car. This was partly compensated in our study by holding the exposimeter at a certain distance from the body.

Other studies have measured the exposure of RF radiation in public places. In 2012, Estenberg and Augustsson (43) used a car-mounted device to measure the frequency range 30-3,000 MHz in public places (rural, urban and large cities). The arithmetic mean measured exposure was $6,700 \mu \mathrm{W} / \mathrm{m}^{2}$ in Stockholm, 1,500 $\mu \mathrm{W} / \mathrm{m}^{2}$ in 4 urban towns and $230 \mu \mathrm{W} / \mathrm{m}^{2}$ in 2 rural areas. Similar to our study, the major sources were GSM and UMTS downlinks.

Earlier studies, prior to the use of smartphones, when $3 \mathrm{G}$ and $4 \mathrm{G}$ protocols became more common, reported lower exposure. Joseph et al (44) performed measurements with a personal exposimeter (EME-Spy 120-121) in different urban areas across Europe during 2007-2009. They found mean values for outdoor areas of $372-569 \mu \mathrm{W} / \mathrm{m}^{2}$, mostly from mobile communications. In 2010, Bolte and Eikelboom (45) also performed measurements in The Netherlands with a personal exposimeter (EME-Spy 121) and found a mean value in outdoor activities of $208 \mu \mathrm{W} / \mathrm{m}^{2}$. Visits to pubs, cafés, discos and snack bars yielded the highest mean value in their study $\left(526 \mu \mathrm{W} / \mathrm{m}^{2}\right)$, mostly from mobile uplink at 1,800 MHz. Urbinello et al (46) used the same exposimeter in three different European cities (Basel, Ghent and Brussels), every month for 1 year (April, 2011-March, 2012). The 


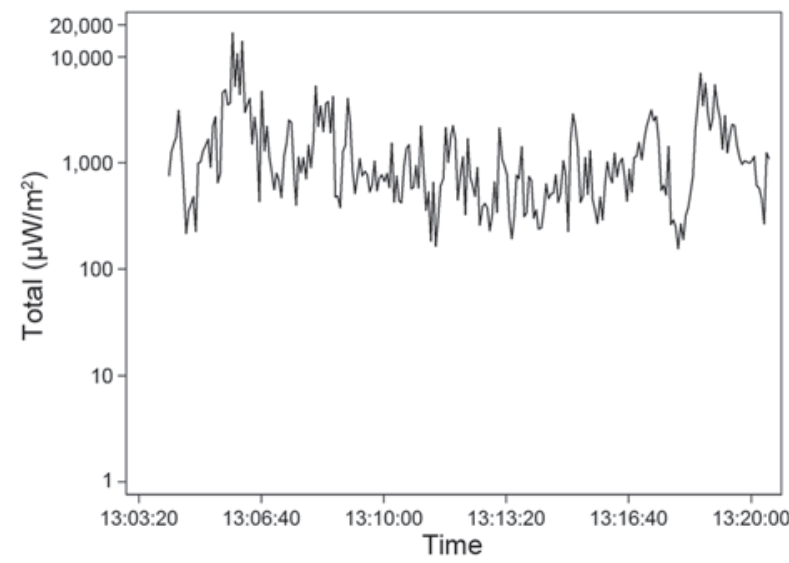

Figure 10. Stockholm, Swedish Parliament. Total radiofrequency field exposure (mean exposure, $1,460.2 \mu \mathrm{W} / \mathrm{m}^{2}$, logarithmic scale) over time of one typical exposure round (11 April, 2016; time, 13:04:09-13:20:29).

total from all sources of RF radiation in downtown outdoor areas increased by $56 \%$ in Basel, $27 \%$ in Ghent and $25 \%$ in Brussels. The mean levels were 0.32-0.58 V/m (271-892 $\mu \mathrm{W} /$ $\mathrm{m}^{2}$ ). In 2012, Aerts et al (47) conducted measurements in an urban/suburban area of Ghent, Belgium covering an area of $1 \mathrm{~km}^{2}$. They selected $0.7 \mathrm{~V} / \mathrm{m}\left(1,300 \mu \mathrm{W} / \mathrm{m}^{2}\right)$ as a threshold for a hotspot and found five hotspots in the area. GSM 900 base station signals contributed the most to all five hotspots with 45-100\%, with GSM 1800 and 3G present in two of the hotspots.

Verlock et al (48) used a Narda NBM-550 in public places in Belgium during 2012-2013. The total average from all RF radiation sources between $100 \mathrm{kHz}$ and $3 \mathrm{GHz}$ was $0.62 \mathrm{~V} / \mathrm{m}\left(1,020 \mu \mathrm{W} / \mathrm{m}^{2}\right)$, with a maximum of $2.4 \mathrm{~V} / \mathrm{m}$ $\left(15,287 \mu \mathrm{W} / \mathrm{m}^{2}\right)$.

Calvente et al (49) conducted measurements outside the homes of 123 families in Granada, Spain during 2012-2013. The arithmetic mean root square (RMS) for power density was $799 \mu \mathrm{W} / \mathrm{m}^{2}$ and the median value was $285 \mu \mathrm{W} / \mathrm{m}^{2}$. For the different homes, the median RMS ranged from 5 to $11,559 \mu \mathrm{W} / \mathrm{m}^{2}$. In 2015, Gonzalez-Rubio et al (50) used an EME-Spy 140 located inside the plastic basket of a bicycle. With this bicycle they covered all 110 regions in the city of Albecete, Spain, performing measurements. The average for the 3 bands of mobile telephone antennas (GSM, Digital Combat Simulator and UMTS) in the different regions varied from $0.04 \mathrm{~V} / \mathrm{m}\left(4.2 \mu \mathrm{W} / \mathrm{m}^{2}\right)$ to $0.89 \mathrm{~V} / \mathrm{m}\left(2,102 \mu \mathrm{W} / \mathrm{m}^{2}\right)$.

The mean values for exposure to $\mathrm{RF}$ radiation from the earlier studies indicate a clear increase in the more recent exposimeter studies. It is clear from our present and previous (1) studies that the level of ambient RF radiation exposure is increasing. With the development of mobile communications technologies and the widespread use of wireless services, the exposure will continue to increase with higher exposure levels and also other frequency bands, despite the already proven adverse health effects.

Long-term studies with laboratory animals at or below the levels in the present study have shown the effects of RF radiation on several physiological parameters in the body of mammals. These are non-thermal effects and are discussed briefly below, including a few human studies.

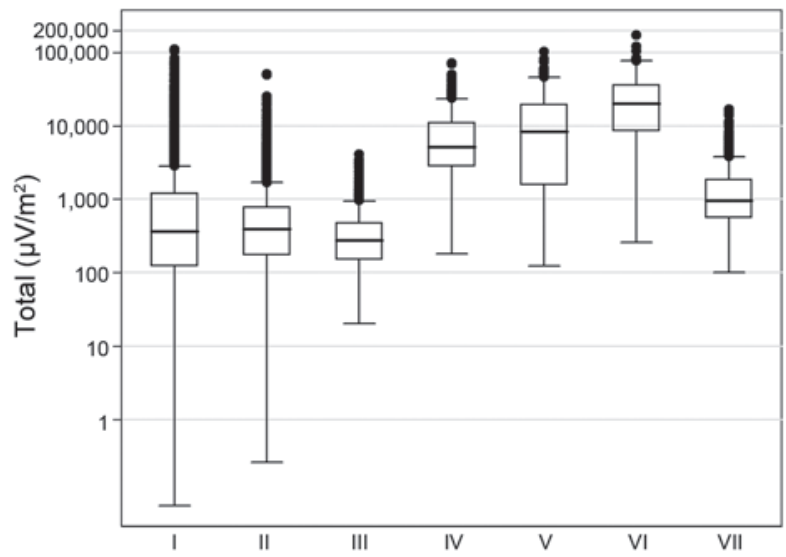

Figure 11. Box plot, total exposure $\left(\mu \mathrm{W} / \mathrm{m}^{2}\right)$, all locations, logarithmic scale for the measurement rounds. The median is indicated by the black line inside each box; the bottom and top of the boxes represent the first and third quartiles; the end of the whiskers are calculated as $1.5 \mathrm{x}$ interquartile range. The points represent the outliers. I=Stockholm Old Town; II=Royal Castle; III=Supreme Court; IV=Stortorget; V=Kornhamnstorg; VI=Järntorget; $\mathrm{VII}=$ Swedish Parliament.

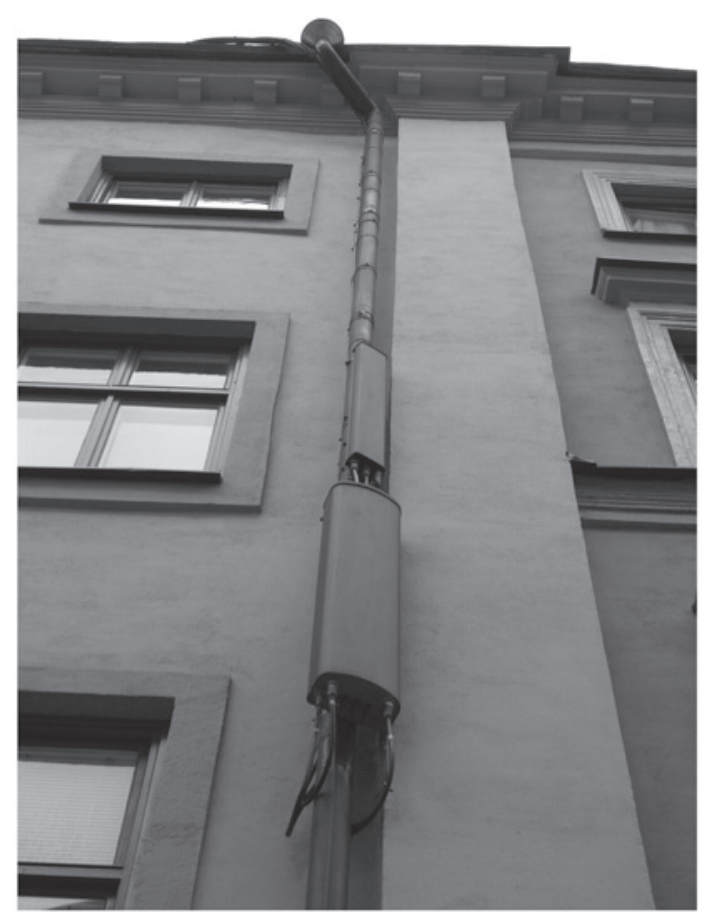

Figure 12. Stockholm Old Town measurement location with a relatively high radiofrequency radiation level, due to a mobile telephony base station antenna positioned at a low height and targeted towards the square.

Several studies on rats have demonstrated that the blood-brain barrier (BBB) may open when exposed to RF radiation, resulting in pathological leakage of large molecules that may be toxic to the brain, with condensed dark neurons in the brain representing a sign of damage (51-54). The hippocampus, a center for memory and learning in the brain, appears to be particularly sensitive to neuronal damage from RF radiation and an opened BBB. Long-term exposure to $900 \mathrm{MHz}$ RF radiation has been associated with extravasation of albumin in the hippocampus and cortex and impaired spatial memory in exposed rats (55-57). 
A long-term study with exposure from GSM $900 \mathrm{MHz} 3 \mathrm{~h} /$ day or DECT base station $8 \mathrm{~h}$ /day during 8 months reported a statistically significant downregulation or an overexpression for one-third of the 432 analyzed proteins from the brains of the RF-irradiated mice. Several neural function-related proteins, such as apolipoprotein $\mathrm{E}$, heat shock proteins and cytoskeletal proteins, as well as proteins involved in brain metabolism, were altered (58).

Up to 12 months of exposure to Wi-Fi exerted an effect on microRNA in the brain (59) and in the testes, with head defects and DNA damage in sperm cells (60-62).

Yakymenko et al (41) published a review of 100 studies investigating the oxidative effects of low-intensity RF radiation in living cells, and demonstrated that exposure down to $2,500 \mu \mathrm{W} / \mathrm{m}^{2}$ (63) with $\mathrm{SAR}$ values as low as $600 \mu \mathrm{W} / \mathrm{kg}(64,65)$ may increase oxidative stress in the cells. Long-term, low-intensity RF radiation exposure has also been associated with reduced levels of neurotransmitters, downregulation of microRNA, increase in pro-inflammatory cytokines and DNA damage with single-strand breaks in the hippocampus and cognitive impairments in learning and memory in exposed rats (65-67). An increase in frequency appears to exert more deleterious effect on several of the parameters (66).

Exposure levels in rats down to a SAR of $85 \mu \mathrm{W} / \mathrm{kg}$, for $900 \mathrm{MHz}$ during $2 \mathrm{~h} /$ day, 5 days/week for 30 days, increased the oxidative stress parameters in lipid peroxidation and protein oxidation. In addition, there was a statistically significant impairment in cognitive function in terms of spatial memory in the rats (68).

$\mathrm{RF}$ radiation has been shown to increase protein synthesis in proliferating human cells after $8 \mathrm{~h}$ of exposure, but not in quiescent white blood cells. This indicates a higher sensitivity of growing organisms (69). Furthermore, the capacity to repair DNA double-strand breaks was more affected by RF radiation in stem cells compared with differentiated cells, such as fibroblasts (70).

Epidemiological studies of mobile phone base stations have indicated health risks for humans. In particular, increased prevalence of adverse neurobehavioral symptoms or cancer in populations living at a distance of $<500 \mathrm{~m}$ from base stations was found in $80 \%$ of the available studies in a review by Khurana et al (71). In another review, Levitt and Lai (72) included 56 studies. Exposure from base stations and other antenna arrays brought about changes in the immunological and reproductive systems of animals and humans, changes in biological material, DNA double-strand breaks, changes in calcium movement in the heart and increased proliferation rates in human astrocytoma cancer cells.

Long-term studies on low exposure to RF radiation of humans have demonstrated an effect on the neurotransmitters adrenaline, noradrenaline, dopamine and phenyletylamine when a GSM $900 \mathrm{MHz}$ base station was installed in the village of Rimbach in Germany (73), as well as on cortisol and thyroid gland hormones in individuals living near base stations $(74,75)$. Chronic dysregulation of psychobiological stress markers may contribute to health problems and chronic illnesses.

The results from these studies report levels of environmental exposure to RF radiation below the ICNIRP target level $(2,3)$, but far above the BioInitiative Report level for biological effects $(5,6)$. It has been argued that the BioInitiative Reports are not peer-reviewed. However, peer-reviewed and published studies also document health effects at low RF radiation levels $(76,77)$. A recent article highlights the need for accurate information on the safety of exposure to RF radiation (78).

In conclusion, the aim of our study was to assess outdoor exposure to RF radiation at the Old Town and the nearby Parliament in Stockholm, Sweden. The Old Town is a part of Stockholm that is very popular among tourists, but also a destination for locals visiting the official buildings located in the area. In this study, real-time band-specific exposure measurements showed the highest contributors to the exposure to be download frequencies from the base stations of GSM + UMTS 900, UMTS 2100, LTE 800, LTE 2600 and GSM 1800 bands. The highest mean levels were found for GSM + UMTS 900 (3G) downlink and LTE 2600 (4G) downlink. The differences in exposure levels between the Supreme Court and Järntorget were striking, with the mean level 60 times higher at Järntorget. Unfortunately, studies on human risk from long-term environmental RF radiation based on personal exposure monitoring do not exist to the best of our knowledge. Future studies on cancer risk and other health effects from such exposure are imperative. The results of this study revealed unnecessarily high RF radiation areas in several parts of Stockholm Old Town. Using unnecessarily high power levels and placing mobile phone base station antennas too close to the ground and in heavily frequented areas pose an excess health risk to a significant part of the population.

\section{Acknowledgements}

The present study was supported by grants from Mr. Brian Stein, Cancer- och Allergifonden, Cancerhjälpen, and Pandora-Foundation for Independent Research, Berlin, Germany.

\section{References}

1. Hardell L, Koppel T, Carlberg M, Ahonen M and Hedendahl L: Radiofrequency radiation at Stockholm Central Railway Station in Sweden and some medical aspects on public exposure to RF fields. Int J Oncol 49: 1315-1324, 2016.

2. Guidelines for limiting exposure to time-varying electric, magnetic, and electromagnetic fields (up to $300 \mathrm{GHz}$ ). International Commission on Non-Ionizing Radiation Protection. Health Phys 74: 494-522, 1998.

3. ICNIRP statement on the 'Guidelines for limiting exposure to time-varying electric, magnetic and electromagnetic fields (up to $300 \mathrm{GHz}$ '. Health Phys 97: 257-258, 2009.

4. Hedendahl L, Carlberg M and Hardell L: Electromagnetic hypersensitivity-an increasing challenge to the medical profession. Rev Environ Health 30: 209-215, 2015.

5. BioInitiative Working Group: BioInitiative Report: A Rationale for a Biologically-based Public Exposure Standard for Electromagnetic Fields (ELF and RF). Sage C and Carpenter DO (eds). Bioinitiative, 2007. Available online: http://www.bioinitiative.org/table-of-contents/. Accessed October 3, 2016.

6. BioInitiative Working Group: BioInitiative 2012. A Rationale for a Biologically-based Public Exposure Standard for Electromagnetic Fields (ELF and RF). Sage C and Carpenter DO (eds.). Bioinitiative, 2012. Available online: http://www.bioinitiative.org/table-of-contents/. Accessed October 3, 2016.

7. Szmigielski S, Szudzinski A, Pietraszek A, Bielec M, Janiak M and Wrembel JK: Accelerated development of spontaneous and benzopyrene-induced skin cancer in mice exposed to $2450-\mathrm{MHz}$ microwave radiation. Bioelectromagnetics 3: 179-191, 1982. 
8. Cleary SF, Liu LM and Merchant RE: Glioma proliferation modulated in vitro by isothermal radiofrequency radiation exposure. Radiat Res 121: 38-45, 1990.

9. Cleary SF, Liu LM and Merchant RE: In vitro lymphocyte proliferation induced by radio-frequency electromagnetic radiation under isothermal conditions. Bioelectromagnetics 11: 47-56, 1990.

10. Chou CK, Guy AW, Kunz LL, Johnson RB, Crowley JJ and Krupp JH: Long-term, low-level microwave irradiation of rats. Bioelectromagnetics 13: 469-496, 1992.

11. Repacholi MH, Basten A, Gebski V, Noonan D, Finnie J and Harris AW: Lymphomas in E mu-Pim1 transgenic mice exposed to pulsed $900 \mathrm{MHZ}$ electromagnetic fields. Radiat Res 147 631-640, 1997.

12. Utteridge TD, Gebski V, Finnie JW, Vernon-Roberts B and Kuchel TR: Long-term exposure of E-mu-Pim1 transgenic mice to $898.4 \mathrm{MHz}$ microwaves does not increase lymphoma incidence. Radiat Res 158: 357-364, 2002.

13. Hardell L, Eriksson M, Carlberg M, Sundström C and Mild KH Use of cellular or cordless telephones and the risk for non-Hodgkin's lymphoma. Int Arch Occup Environ Health 78: 625-632, 2005.

14. Linet MS, Taggart T, Severson RK, Cerhan JR, Cozen W, Hartge P and Colt J: Cellular telephones and non-Hodgkin lymphoma. Int J Cancer 119: 2382-2388, 2006

15. Carlberg M, Hedendahl L, Ahonen M, Koppel T and Hardell L: Increasing incidence of thyroid cancer in the Nordic countries with main focus on Swedish data. BMC Cancer 16: 426, 2016.

16. Lauer O, Frei P, Gosselin MC, Joseph W, Röösli M and Fröhlich J Combining near- and far-field exposure for an organ-specific and whole-body RF-EMF proxy for epidemiological research: A reference case. Bioelctromagnetics 34: 366-374, 2013.

17. $\mathrm{Lu} \mathrm{M}$ and Wu XY: Study of specific absorption rate (SAR) induced in human endocrine glands for using mobile phones. IEEE Asia-Pacific International Symposium on Electromagnetic Compatibility (APEMC): 1084-1086, 2016.

18. Tillmann T, Ernst H, Streckert J, Zhou Y, Taugner F, Hansen V and Dasenbrock CT: Indication of cocarcinogenic potential of chronic UMTS-modulated radiofrequency exposure in an ethylnitrosourea mouse model. Int J Radiat Biol 86: 529-541, 2010.

19. Lerchl A, Klose M, Grote K, Wilhelm AF, Spathmann O, Fiedler T, Streckert J, Hansen V and Clemens M: Tumor promotion by exposure to radiofrequency electromagnetic fields below exposure limits for humans. Biochem Biophys Res Commun 459: 585-590, 2015.

20. Wyde M, Cesta M, Blystone C, Elmore S, Foster P, Hooth M Kissling G, Malarkey D, Sills R, Stout M, et al: Report of Partia Findings from the National Toxicology Program Carcinogenesis Studies of Cell Phone Radiofrequency Radiation in Hsd: Sprague Dawley ${ }^{\circledR}$ SD rats (Whole Body Exposures). Draft 5-19-2016. US National Toxicology Program (NTP), 2016. doi: http://dx.doi org/10.1101/055699. Available online: http://biorxiv.org/content/ biorxiv/early/2016/05/26/055699.full.pdf. Accessed October 3 , 2016.

21. Lai H and Singh NP: Acute low-intensity microwave exposure increases DNA single-strand breaks in rat brain cells Bioelectromagnetics 16: 207-210, 1995.

22. Hardell L, Näsman A, Påhlson A, Hallquist A and Hansson Mild K: Use of cellular telephones and the risk for brain tumours: A case-control study. Int J Oncol 15: 113-116, 1999.

23. Hardell L, Hansson Mild K, Påhlson A and Hallquist A: Ionizing radiation, cellular telephones and the risk for brain tumours. Eur J Cancer Prev 10: 523-529, 2001.

24. Hardell L, Hallquist A, Mild KH, Carlberg M, Påhlson A and Lilja A: Cellular and cordless telephones and the risk for brain tumours. Eur J Cancer Prev 11: 377-386, 2002.

25. Hardell L, Mild KH and Carlberg M: Further aspects on cellular and cordless telephones and brain tumours. Int J Oncol 22 : 399-407, 2003

26. Baan R, Grosse Y, Lauby-Secretan B, El Ghissassi F, Bouvard V, Benbrahim-Tallaa L, Guha N, Islami F, Galichet L and Straif K WHO International Agency for Research on Cancer Monograph Working Group: Carcinogenicity of radiofrequency electromagnetic fields. Lancet Oncol 12: 624-626, 2011

27. IARC Monographs on the Evaluation of Carcinogenic Risks to Humans, Volume 102. Non-Ionizing Radiation, Part 2: Radiofrequency Electromagnetic Fields. International Agency for Research on Cancer: Lyon, France, 2013. Available online: http://monographs.iarc.fr/ENG/Monographs/vol102/mono102. pdf. Accessed October 3, 2016
28. Hardell L, Carlberg M and Hansson Mild K: Pooled analysis of two case-control studies on use of cellular and cordless telephones and the risk for malignant brain tumours diagnosed in 1997-2003. Int Arch Occup Environ Health 79: 630-639, 2006.

29. Hardell L, Carlberg M and Hansson Mild K: Pooled analysis of two case-control studies on the use of cellular and cordless telephones and the risk of benign brain tumours diagnosed during 1997-2003. Int J Oncol 28: 509-518, 2006.

30. Hardell L, Carlberg M and Hansson Mild K: Pooled analysis of case-control studies on malignant brain tumours and the use of mobile and cordless phones including living and deceased subjects. Int J Oncol 38: 1465-1474, 2011.

31. Brain tumour risk in relation to mobile telephone use: Results of the INTERPHONE international case-control study. Int J Epidemiol 39: 675-694, 2010.

32. Acoustic neuroma risk in relation to mobile telephone use: Results of the INTERPHONE international case-control study. Cancer Epidemiol 35: 453-464, 2011.

33. Cardis E, Armstrong BK, Bowman JD, Giles GG, Hours M, Krewski D, McBride M, Parent ME, Sadetzki S, Woodward A, et al: Risk of brain tumours in relation to estimated RF dose from mobile phones: Results from five Interphone countries. Occup Environ Med 68: 631-640, 2011

34. Hardell L, Carlberg M, Söderqvist F and Mild KH: Pooled analysis of case-control studies on acoustic neuroma diagnosed 1997-2003 and 2007-2009 and use of mobile and cordless phones. Int J Oncol 43: 1036-1044, 2013.

35. Hardell L, Carlberg M, Söderqvist F and Mild KH: Case-control study of the association between malignant brain tumours diagnosed between 2007 and 2009 and mobile and cordless phone use. Int J Oncol 43: 1833-1845, 2013.

36. Hardell L, Carlberg M and Hansson Mild K: Use of mobile phones and cordless phones is associated with increased risk for glioma and acoustic neuroma. Pathophysiology 20: 85-110, 2013.

37. Hardell L and Carlberg M: Mobile phone and cordless phone use and the risk for glioma-Analysis of pooled case-control studies in Sweden, 1997-2003 and 2007-2009. Pathophysiology 22: 1-13, 2015.

38. Coureau G, Bouvier G, Lebailly P, Fabbro-Peray P, Gruber A, Leffondre K, Guillamo JS, Loiseau H, Mathoulin-Pélissier S, Salamon R and Baldi I: Mobile phone use and brain tumours in the CERENAT case-control study. Occup Environ Med 71: 514-522, 2014

39. Hardell L and Carlberg M: Using the Hill viewpoints from 1965 for evaluating strengths of evidence of the risk for brain tumors associated with use of mobile and cordless phones. Rev Environ Health 28: 97-106, 2013.

40. Hill AB: The environment and disease: Association or causation? Proc R Soc Med 58: 295-300, 1965.

41. Yakymenko I, Tsybulin O, Sidorik E, Henshel D, Kyrylenko O and Kyrylenko S: Oxidative mechanisms of biological activity of low-intensity radiofrequency radiation. Electromagn Biol Med 35: 186-202, 2016

42. Bolte JF, Maslanyj M, Addison D, Mee T, Kamer J and Colussi L: Do car-mounted mobile measurements used for radio-frequency spectrum regulation have an application for exposure assessments in epidemiological studies? Environ Int 86: 75-83, 2016.

43. Estenberg J and Augustsson T: Extensive frequency selective measurements of radiofrequency fields in outdoor environments performed with a novel mobile monitoring system. Bioelectromagnetics 35: 227-230, 2014.

44. Joseph W, Frei P, Röösli M, Thuróczy G, Gajsek P, Trcek T, Bolte J, Vermeeren G, Mohler E, Juhász P, et al: Comparison of personal radio frequency electromagnetic field exposure in different urban areas across Europe. Environ Res 110: 658-663, 2010.

45. Bolte JF and Eikelboom T: Personal radiofrequency electromagnetic field measurements in The Netherlands: Exposure level and variability for everyday activities, times of day and types of area. Environ Int 48: 133-142, 2012.

46. Urbinello D, Joseph W, Verloock L, Martens L and Röösli M: Temporal trends of radio-frequency electromagnetic field (RF-EMF) exposure in everyday environments across European cities. Environ Res 134: 134-142, 2014.

47. Aerts S, Deschrijver D, Verloock L, Dhaene T, Martens L and Joseph W: Assessment of outdoor radiofrequency electromagnetic field exposure through hotspot localization using kriging-based sequential sampling. Environ Res 126: 184-191, 2013. 
48. Verlock L, Joseph W, Goeminne F, Martens L, Verlaek M and Constandt K: Assessment of radiofrequency exposures in schools, homes, and public places in Belgium. Health Phys 107: 503-513, 2014.

49. Calvente I, Fernández MF, Pérez-Lobato R, Dávila-Arias C Ocón O, Ramos R, Ríos-Arrabal S, Villalba-Moreno J, Olea N and Núñez MI: Outdoor characterization of radio frequency electromagnetic fields in a Spanish birth cohort. Environ Res 138: 136-143, 2015.

50. Gonzalez-Rubio J, Najera A and Arribas E: Comprehensive personal RF-EMF exposure map and its potential use in epidemiological studies. Environ Res 149: 105-112, 2016.

51. Eberhardt JL, Persson BR, Brun AE, Salford LG and Malmgren LO: Blood-brain barrier permeability and nerve cell damage in rat brain 14 and 28 days after exposure to microwaves from GSM mobile phones. Electromagn Biol Med 27: 215-229, 2008.

52. Salford LG, Brun AE, Eberhardt JL, Malmgren L and Persson BR: Nerve cell damage in mammalian brain after exposure to microwaves from GSM mobile phones. Environ Health Perspect 111: 881-883, A408, 2003.

53. Nittby H, Brun A, Eberhardt J, Malmgren L, Persson BR and Salford LG: Increased blood-brain barrier permeability in mammalian brain 7 days after exposure to the radiation from a GSM-900 mobile phone. Pathophysiology 16: 103-112, 2009.

54. Sirav B and Seyhan N: Effects of GSM modulated radio-frequency electromagnetic radiation on permeability of blood-brain barrier in male \& female rats. J Chem Neuroanat 75: 123-127, 2016.

55. Tang J, Zhang Y, Yang L, Chen Q, Tan L, Zuo S, Feng H, Chen Z and Zhu G: Exposure to $900 \mathrm{MHz}$ electromagnetic fields activates the mkp-1/ERK pathway and causes blood-brain barrier damage and cognitive impairment in rats. Brain Res 1601: 92-101, 2015.

56. Nittby H, Grafström G, Tian DP, Malmgren L, Brun A Persson BR, Salford LG and Eberhardt J: Cognitive impairment in rats after long-term exposure to GSM-900 mobile phone radiation. Bioelectromagnetics 29: 219-232, 2008.

57. Grafström G, Nittby H, Brun A, Malmgren L, Persson BR, Salford LG and Eberhardt J: Histopathological examinations of rat brains after long-term exposure to GSM-900 mobile phone radiation. Brain Res Bull 77: 257-263, 2008.

58. Fragopoulou A, Samara A, Antonelou MH, Xanthopoulou A, Papadopoulou A, Vougas K, Koutsogiannopoulou E, Anastasiadou E, Stravopodis DJ, Tsangaris GT and Margaritis LH: Brain proteome response following whole body exposure of mice to mobile phone or wireless DECT base radiation. Electromagn Biol Med 31: 250-274, 2012.

59. Dasdag S, Akdag MZ, Erdal ME, Erdal N, Ay OI, Ay ME, Yilmaz SG, Tasdelen B and Yegin K: Effects of $2.4 \mathrm{GHz}$ radiofrequency radiation emitted from Wi-Fi equipment on microRNA expression in brain tissue. Int J Radiat Biol 91: 555-561, 2015

60. Dasdag S, Tas M, Akdag MZ and Yegin K: Effect of long-term exposure of $2.4 \mathrm{GHz}$ radiofrequency radiation emitted from Wi-Fi equipment on testes functions. Electromagn Biol Med 34: $37-42,2015$

61. Avendaño C, Mata A, Sanchez Samiento CA and Doncel GF: Use of laptop computers connected to internet through Wi-Fi decreases human sperm motility and increases sperm DNA fragmentation. Fertil Steril 97: 39-45.e2, 2012.

62. Akdag MZ, Dasdag S, Canturk F, Karabulut D, Caner Y and Adalier N: Does prolonged radiofrequency radiation emitted from Wi-Fi devices induce DNA damage in various tissues of rats? J Chem Neuroanat 75: 116-122, 2016.

63. Burlaka A, Tsybulin O, Sidorik E, Lukin S, Polishuk V, Tsehmistrenko S and Yakymenko I: Overproduction of free radical species in embryonal cells exposed to low intensity radiofrequency radiation. Exp Oncol 35: 219-225, 2013.
64. Megha K, Deshmukh PS, Banerjee BD, Tripathi AK and Abegaonkar MP: Microwave radiation induced oxidative stress, cognitive impairment and inflammation in brain of Fischer rats. Indian J Exp Biol 50: 889-896, 2012.

65. Megha K, Deshmukh PS, Ravi AK, Tripathi AK, Abegaonkar MP and Banerjee BD: Effect of low-intensity microwave radiation on monoamine neurotransmitters and their key regulating enzymes in rat brain. Cell Biochem Biophys 73: 93-100, 2015.

66. Megha K, Deshmukh PS, Banerjee BD, Tripathi AK, Ahmed R and Abegaonkar MP: Low intensity microwave radiation induced oxidative stress, inflammatory response and DNA damage in rat brain. Neurotoxicology 51: 158-165, 2015.

67. Deshmukh PS, Nasare N, Megha K, Banerjee BD, Ahmed RS, Singh D, Abegaonkar MP, Tripathi AK and Mediratta PK: Cognitive impairment and neurogenotoxic effects in rats exposed to low-intensity microwave radiation. Int J Toxicol 34: 284-290, 2015.

68. Deshmukh PS, Banerjee BD, Abegaonkar MP, Megha K, Ahmed RS, Tripath AK and Mediratta PK: Effect of low level microwave radiation exposure on cognitive function and oxidative stress in rats. Indian J Biochem Biophys 50: 114-119, 2013.

69. Gerner C, Haudek V, Schandl U, Bayer E, Gundacker N, Hutter HP and Mosgoeller W: Increased protein synthesis by cells exposed to a $1,800-\mathrm{MHz}$ radio-frequency mobile phone electromagnetic field, detected by proteome profiling. Int Arch Occup Environ Health 83: 691-702, 2010.

70. Markovà E, Malmgren LO and Belyaev IY: Microwaves from mobile phones inhibit 53BP1 focus formation in human stem cells more strongly than in differentiated cells: Possible mechanistic link to cancer risk. Environ Health Perspect 118: 394-399, 2010.

71. Khurana VG, Hardell L, Everaert J, Bortkiewicz A, Carlberg M and Ahonen M: Epidemiological evidence for a health risk from mobile phone base stations. Int J Occup Environ Health 16: 263-267, 2010.

72. Levitt BB and Lai H: Biological effects from exposure to electromagnetic radiation emitted by cell tower base stations and other antenna arrays. Environ Rev 18: 369-395, 2010.

73. Buchner $\mathrm{K}$ and Eger $\mathrm{H}$ : Changes of clinically important neurotransmitters under the influence of modulated RF fields-A long-term study under real-life conditions. Umwelt-Medizin-Gesellschaft 24: 44-57, 2011.

74. Augner C, Hacker GW, Oberfeld G, Florian M, Hitzl W, Hutter J and Pauser G: Effects of exposure to GSM mobile phone base station signals on salivary cortisol, alpha-amylase, and immunoglobulin A. Biomed Environ Sci 23: 199-207, 2010.

75. Eskander EF, Estefan SF and Abd-Rabou AA: How does long term exposure to base stations and mobile phones affect human hormone profiles? Clin Biochem 45: 157-161, 2012.

76. Carpenter DO and Sage C: Setting prudent public health policy for electromagnetic field exposures. Rev Environ Health 23: 91-117, 2008

77. Hardell L and Sage C: Biological effects from electromagnetic field exposure and public exposure standards. Biomed Pharmacother 62: 104-109, 2008

78. Starkey SJ: Inaccurate official assessment of radiofrequency safety by the Advisory Group on Non-ionising Radiation. Rev Environ Health 31: 493-503, 2016. 